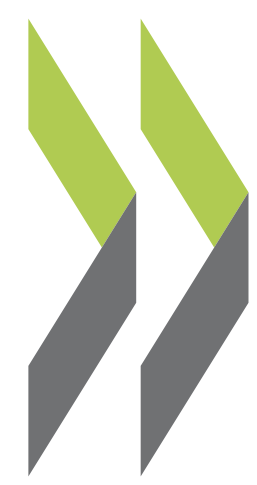

OECD Economics Department Working Papers No. 382

Differences in Resilience Between the Euro-Area and US Economies

\section{Aaron Drew,}

Mike Kennedy,

Torsten Sløk 
Organisation de Coopération et de Développement Economiques

Organisation for Economic Co-operation and Development

04-Mar-2004

ECONOMICS DEPARTMENT

English - Or. English

DIFFERENCES IN RESILIENCE BETWEEN THE EURO-AREA AND US ECONOMIES

ECONOMICS DEPARTMENT WORKING PAPERS NO. 382

by

Aaron Drew, Mike Kennedy and Torsten Sløk

All Economics Department Working Papers are now available through OECD's Internet Web site at http://www.oecd.org/eco 


\section{ABSTRACT/RESUMÉ \\ Differences in resilience between the euro-area and US economies}

This paper is concerned with how stylised differences in monetary policy transmission mechanisms and product and labour market rigidities between the US and euro-area economies affect their resilience to temporary shocks. To address this issue, a small general equilibrium model with long-run neoclassical and short-run neo-Keynesian features is calibrated to replicate the key properties of the US economy (as in the US Fed's FRB-US model). To this model, features of the euro area's financial and then product and labour markets are added sequentially with a view to replicating what is generally agreed are aspects of the functioning of the euro-area economy (as captured by the ECB's Area-Wide Model). Most of the analysis is conducted assuming identical monetary policy reaction functions, although the sensitivity of the results to this assumption is tested. The results illustrate the importance of adjustment patterns in financial, product and labour markets for economies' responses to demand shocks and in determining the appropriate monetary policy reaction.

JEL classification: E21, E22, E30, E52

Keywords: Transmission mechanism, resilience, euro area, labour and product market rigidities, CGE modelling.

******

\section{Les différences, en termes de résilience, entre l'économie américaine et celle de la zone euro}

Ce document étudie les principales différences en matière de transmission de la politique monétaire et de rigidités des marchés des produits et du travail, et leurs effets sur la résilience des économies des États-Unis et de la zone euro aux chocs temporaires. Un petit modèle d'équilibre général, de facture néo-classique sur le long terme et néo-keynésienne sur le court terme, est calibré pour reproduire les comportements clés de l'économie américaine (tels que les décrit le modèle FRB-US de la Banque de réserve fédérale des États-Unis). Des caractéristiques des marchés financiers puis des marchés des produits et du travail de la zone euro sont ensuite incorporées dans le modèle afin de mieux capter certains aspects du fonctionnement de l'économie de la zone euro (tels que les décrit le modèle de la BCE couvrant la zone euro). L'analyse repose largement sur des fonctions de réaction de la politique monétaire identiques, mais l'importance de cette hypothèse est testée. Les résultats illustrent l'importance des mécanismes d'ajustement dans les marchés financiers, des produits et du travail sur les réactions des économies aux chocs de demande, et pour ajuster la politique monétaire de manière appropriée.

Classification JEL : E21, E22, E30, E52

Mots-clés : mécanisme de transmission, résilience, zone euro, rigidités des marchés des produits et du travail, modèle EGC.

\section{Copyright: OECD 2004. All rights reserved.}

Applications for permission to reproduce or translate all, or part, of this material should be made to: Head of Publications Service, OECD, 2 rue André-Pascal, 75775 PARIS CEDEX 16, France. 
ECO/WKP(2004)5

\section{TABLE OF CONTENTS}

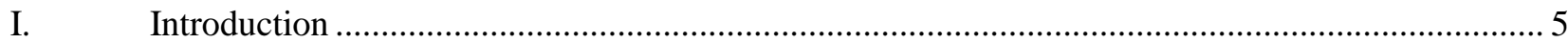

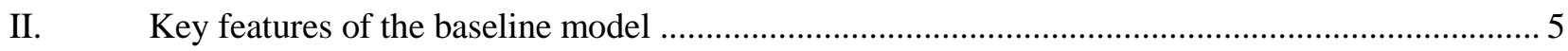

III. The transmission mechanism and the functioning of financial markets........................................ 7

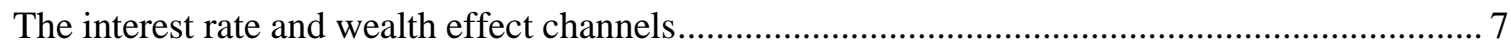

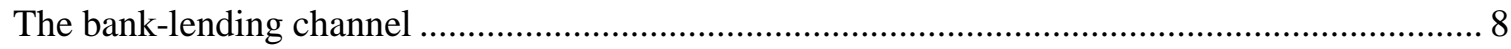

IV. The role of product and labour market rigidities ................................................................... 9

V. Sensitivity tests concerning the policy rule and the type of shock ........................................... 10

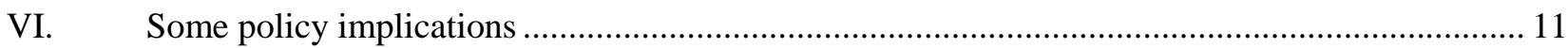

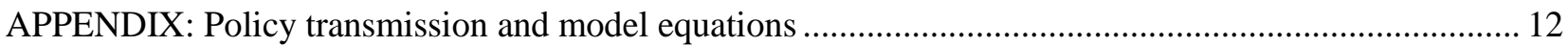

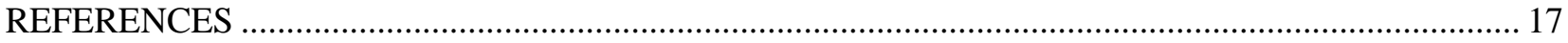

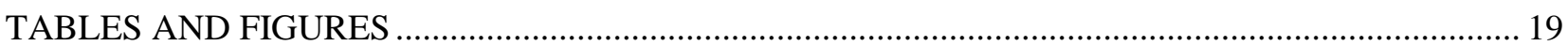




\section{LIST OF TABLES AND FIGURES}

\section{Tables}

1. Effects of monetary policy shocks in FRB-US model compared with OECD stylised model

2. Differences in financial structure in selected countries, 2001

3. Securitisation: United States and Europe

4. Profitability of major banks

5. $\quad$ Firm size in selected countries

6. Effects of monetary policy shocks in euro-area models compared with the OECD stylised model calibrated to incorporate euro-area features

\section{Figures}

1. Pass-through of policy rates to market rates

2. Ratio of gross financial wealth to gross wealth in the household sector

3. The effect of a weaker interest rate channel

4. Bank loans as share of GDP

5. The effect of bank lending and weaker interest rate channels

6. Details of the investment response with bank lending and weaker interest rate channels

7. Impact of rigidities and a weaker transmission channel: euro-area versus US model

8. Sensitivity tests: more aggressive policy rule

9. Sensitivity tests: very aggressive policy rule

10. Loss of the euro-area economy relative to the US economy under different shocks 
ECO/WKP(2004)5

\title{
DIFFERENCES IN RESILIENCE BETWEEN THE EURO-AREA AND US ECONOMIES
}

\author{
by
}

Aaron Drew, Mike Kennedy and Torsten Sløk ${ }^{1}$

\section{Introduction}

1. This paper is concerned with how stylised differences in monetary policy transmission mechanisms and product and labour market rigidities between the US and euro-area economies may affect their resilience to temporary shocks. ${ }^{2}$ The analysis begins in Section II with a description of a small simulation model of the United States, which replicates some key properties of the well-known Federal Reserve Board's FRB-US model of the US economy. To this model, a weaker and slower monetary policy transmission mechanism is added to reflect evidence on the functioning of financial markets in the euro area. Under a demand shock and a given policy rule, the weaker transmission mechanism results in more volatile output and prices as monetary policy is less able to buffer the economy (Section III). However, for the model to replicate what is known about how the euro area responds to shocks, as for instance captured by the ECB's Area-Wide Model, it is necessary to make additional changes to reflect rigidities in product and labour markets (Section IV). Such rigidities are proxied in the euro-area model by lengthening lag structures in price and wage setting (i.e. greater nominal rigidities) and by reducing the weight that any disequilibria have on behaviour (i.e. greater real rigidities). The result of such rigidities is that monetary policy is less able to cushion shocks, even if the policy approach is more activist and real interest rates deviate further and for longer from neutral settings (Section V). The final section presents some policy conclusions.

\section{Key features of the baseline model}

2. The simulation model has a quarterly frequency and a two-tiered structure: an underlying steadystate that determines the long-run equilibrium and a dynamic adjustment structure that traces how the economy converges towards it. The long run can be described by a neo-classical balanced growth path, while the short run incorporates "new-Keynesian" features such as price and wage stickiness. The focus of the model is on the short-run dynamics, and how an economy adjusts in the face of temporary shocks.

1. Aaron Drew is a member of the Structural Policy Division, while Mike Kennedy and Torsten Sløk are members of the Money and Finance Division, all of the Economics Department of the OECD. They would like to thank Jean-Philippe Cotis, Mike Feiner, Jørgen Elmeskov, Vincent Koen and Anne-Marie Brook for helpful comments and suggestions. They also wish to thank Catherine Lemoine and Laure Meuro for statistical assistance and Veronica Humi, Paula Simonin and Sandra Raymond for secretarial help. The views expressed here are those of the authors and do not necessarily represent those of the OECD.

2. Resilience can be thought of as how quickly an economy returns to equilibrium following a shock. 
3. The equilibrium path of the model is determined by the interaction between five economic agents: households, firms, the government, the monetary authority and foreign agents. Households maximise utility, firms maximise profits and the government achieves exogenously set targets for debt and expenditures. In addition, the foreign sector trades in goods and assets with the domestic economy. Taken together, the actions of these agents determine expenditure flows that are consistent with a set of stock equilibrium conditions (including the capital stock, government debt, net foreign assets and household wealth) that underlie the balanced-growth path. The dynamic adjustment process overlaid on the equilibrium structure embodies both "expectational" and "intrinsic" dynamics, along with error-correction mechanisms. Expectational dynamics arise through the interaction of exogenous disturbances, policy actions and private agents' expectations. Policy actions are required in order to re-anchor expectations when disturbances move the economy away from equilibrium. However, reflecting the fact that such actions may not immediately re-anchor private expectations in the real world, expectations are modelled either as backward-looking or as a linear combination of backward and forward-looking elements. Intrinsic dynamics and error correction mechanisms are included to reflect adjustment costs and rigidities. Errorcorrection mechanisms are employed in the price and wage-setting equations, while more general mechanisms of adjustment are used elsewhere, based on the polynomial adjustment cost framework described in Tinsley (1993).

4. On the supply side the model produces a single good using Cobb-Douglas production technology. This good is differentiated in its use by a system of relative prices. Overlaid on this system of relative prices is a price-wage setting process developed by Layard et al., (1991) that determines core inflation, with the specific form of the equations based on estimation work in the OECD by Turner et al., (1996). This specification is discussed in detail in the Appendix.

5. The monetary authority effectively closes the model by enforcing a nominal anchor. Its behaviour is modelled by a forward-looking reaction function that moves the short-term nominal interest rate in response to the projected deviations of inflation from an exogenously specified rate and in response to the current deviations of output from potential, subject to a smoothing constraint on the instrument (as in Judd and Rudebusch, 1998). Although the reaction function is ad hoc in the sense that it is not the solution to a pre-defined optimal control problem, its calibration is within the range of the so-called "forward-looking Taylor rules" that are in use in macroeconomic models in various policy-making institutions -- presumably because such rules deliver interest-rate responses that, at least as a first approximation, are seen as reasonable by actual policy makers. Movements in the policy instrument also affect the real exchange rate via a standard real uncovered interest parity (UIP) condition. However, given the empirical weakness of UIP in the short run, lags are introduced into the determinants of the actual and expected real exchange rates to ensure they do not immediately jump to the level implied by the interest rate differentials.

6. Using this framework, a baseline model, which assumes a strong operating interest-rate channel along with flexible wage and price settings, is calibrated to mimic some broad features of the US economy, as represented by the FRB/US model (Table 1). This model is then simulated to illustrate in turn how differences in monetary transmission and labour and product market rigidities affect the response of the stylised economy to a demand shock. 


\section{The transmission mechanism and the functioning of financial markets}

7. As a first step to replicating the broad features of the euro-area economy, a damped interest-rate and a bank-lending channel ${ }^{3}$ are added sequentially to the model in the following subsections. ${ }^{4}$

\section{The interest rate and wealth effect channels}

8. The interest-rate channel has "pride of place" among explanations of the working of the monetary policy transmission mechanism in both the United States and the euro area. ${ }^{5}$ Its efficacy depends, in part, on how quickly policy changes influence the whole spectrum of other rates that are charged to borrowers and this aspect of the process appears to function more strongly in the United States compared with the euro area. In particular:

- US capital markets are larger and more diversified than those in the euro area (Table 2). For example, both stock and private-bond market capitalisation are higher in the US market. While firms in the euro area are moving from local bank borrowing towards issuing securities, this process still has some distance to go to approach that of the United States.

- A number of changes to the regulatory framework over recent decades have improved competition in financial markets in the US economy. ${ }^{6}$ In the euro area the advent of the single currency, as well as other changes, have also had similar effects, but the process is far from complete. $^{7}$

- Another notable difference is the size and extent of securitisation for mortgages and other types of consumer loans, like automobiles and credit cards, as well as for business liabilities (Table 3). Securitisation has the effect of making interest rates on new borrowing more responsive to market rates. This development has been particularly important for the United States, transforming the mortgage market from one that was regional and local to one that is now more economy-wide in scope and strengthening the link from interest rates to house prices. It has also tended to enhance competition, and this has lowered the costs of initiating mortgages, easing the access of households to housing equity withdrawal and refinancing at better terms when interest rates are low. ${ }^{8}$ In contrast, the mortgage markets in the euro area

3. The broad credit channel, which highlights pro-cyclical effects arising from movements in risk premiums on lending (Hubbard, 1998) is not included. There is little evidence that this channel is important at the level of the macro economy in the euro area. There is some evidence that it is operative, in an asymmetrical fashion, in the US economy (Oliner and Rudebusch, 1996). In any event, in the CGE types of models like that used above, such a channel is typically modelled by lowering the coefficient on the effect of interest rates on demand, which is also the manner in which a weaker interest rate channel is modelled in this paper, following Bean et al., 2002.

4. Not dealt with explicitly here is the transmission of monetary policy through the exchange rate channel. Based on OECD work, the effect on output and inflation of a 10 per cent change in their effective exchange rates is similar by the second or third year for the US and euro-area economies, although there are some initial year differences (Dalsgaard et al., 2001).

5. See Angeloni et al., (2003a) and (2003b).

6. See Sellon (2002) for a description of some of these.

7. See OECD (2002).

8. $\quad$ See Todd (2001) for a description. 
are still heterogeneous, domestic in their orientation and have relatively high transaction costs. ${ }^{9}$

9. As an illustration of how these features may influence the degree of pass-through from policy rates to those on other market instruments, the coefficients of the change in policy rates with those on longer-term government bond rates, taken from a simple model of interest rate determination, are shown for two separate time periods in Figure 1 for each economy (where Germany is assumed to proxy the euroarea economy). As can be seen, the coefficient showing the response of long rates to a policy change in each economy was about the same up until the start of the 1990s. Since then, that coefficient has risen in the case of the United States, but has remained more or less unchanged for the euro area.

10. Wealth effects also look to be more important in the United States, in part because of the composition of asset holdings. Examining the past three years, US households, on average, hold a higher proportion of their assets in financial instruments (bonds and equities), that are more sensitive to changing market conditions, than do households in the euro area (Figure 2). In Germany, Italy and somewhat in France, a larger part of total wealth is in non-financial assets, principally housing. While house prices are also sensitive to interest rate and demand developments, wealth effects from house-price changes are likely to be faster and stronger in the United States than in the euro area for the reasons indicated above. ${ }^{10}$

11. The weaker interest rate pass-through and wealth effects in the euro area have been incorporated into the simulation model by lengthening the lag of interest rates and lowering their effect on investment and consumption relative to the baseline model which, as discussed above, is taken to represent the US economy (see Appendix for details). The results show that, in response to a negative demand shock, an economy with a weaker interest rate transmission mechanism exhibits a somewhat deeper cyclical trough in inflation and output and more variability, noticeably with respect to prices (Figure 3). As well, it takes a somewhat longer time to return to equilibrium. Furthermore, differences in the response of consumption account for most of the differences in the variation of output, a feature similar to that noted in the literature. $^{11}$

\section{The bank-lending channel}

12. Both banks and capital markets may in some cases exacerbate cyclical fluctuations, though for different reasons. Hence, economies with diversified financial systems may be less fragile in the context of negative shocks. By contrast, an economy that is heavily reliant on bank intermediation could be more vulnerable to a negative demand shock insofar as it negatively affects bank balance sheets. If, in this situation, these institutions have to fund extra loans with other sources of finance that are imperfect substitutes for deposits, they would likely face an external premium. In consequence, part of their response to a shock could be to cut back on the supply of loans, and borrowers with no or few alternatives to bank loans would be particularly hard hit. The importance of this channel then depends on: first, the size and the health of the banking system; and second, the share of bank-dependent firms in the economy.

13. Turning first to the importance of banks in the financial system, the European economies and Japan look to be significantly more dependent on these institutions as a source of financing than is the case for the United States (Figure 4). As a very imperfect indicator of bank health, pre-tax profits as a share of

9. See OECD (2002).

10. See Boone et al., (2001) and Ludwig and Sløk (2004). Angeloni et al., (2003b) document evidence from larger structural models that consumption plays a larger role in the United States than the euro area in the adjustment back towards equilibrium, and this could be due to stronger wealth effects.

11. See Angeloni et al., (2003a) and Dalsgaard et al., (2002). 
total average assets of major banks in the United States and the United Kingdom have been significantly better during the latest slowdown than they have been in Germany, France and Japan (Table 4).

14. Regarding the second factor, small firms tend to be much more bank-dependent than large ones. Using data on the manufacturing sector only, the proportion of such enterprises relative to the total is higher in the euro area and they also seem to account for a larger share of overall employment and, by extension, presumably also investment (Table 5).

15. A number of empirical studies indeed find support for the existence of a bank-lending channel in the euro area. ${ }^{12}$ In particular, there is evidence that it is important in explaining the response of activity to a policy change in Germany, France, Italy and the Netherlands. ${ }^{13}$ For the United States the evidence is more mixed, with the majority of studies indicating that it is not present, ${ }^{14}$ while those that do find an effect suggest that the overall macro impact is likely to be small. ${ }^{15}$

16. To capture the broad features of such a bank-lending channel, an additional investment equation was created, and incorporated into the model that already takes account of a less powerful interest-rate channel. The new equation represents small firms and capital stock adjustment costs for them are raised to reflect their poorer access to non-bank credit. ${ }^{16}$ This group is assumed to account for 25 per cent of total spending on capital. The large-firm investment function remains the same as that in the previous model. In the simulations, the presence of a bank-lending channel implies that it takes a longer time to adjust to the shock and the required policy response is greater (Figure 5). In addition, beyond the first few years, the swings in output and inflation are large, as also predicted by the bank-lending channel literature.

17. The role that the small-firm investment function plays in the adjustment process at the macro level is significant (Figure 6). In response to a negative demand shock, investment spending of this group initially falls by about the same amount as that of large firms; however, it remains low for a longer period. As a result, when the economy recovers, small firms, after a delay, increase their spending dramatically in order to restore their desired capital stock levels. Consequently, the volatility of total investment for this economy is now larger than in the absence of such a bank-lending channel.

\section{The role of product and labour market rigidities}

18. Dissimilar transmission mechanisms in the US and euro-area economies go only a limited way to account for the differences that are thought to exist in their business-cycle behaviours. Indeed, the larger volatility of activity, inflation and interest rates in the model version with euro-area features seems contrary to received wisdom about euro-area dynamics. ${ }^{17}$ Against this background, the version of the model that included both the slower-working interest-rate and the bank-lending channels was modified to

12. See Kashyap and Stein (1997).

13. See, respectively, de Bondt (1998), Worms (2001), Kakes and Sturm (2002), de Bondt (1999), Loupias et al., (2001) and Chatelain et al., (2001).

14. See for example Oliner and Rudebusch $(1995,1996)$.

15. This is the conclusion of Kashyap et al., (1993), and Kashyap and Stein (2000).

16. This follows in the spirit of Bean et al., (2002), who allow for the existence of credit-constrained firms by lengthening the lag in the IS curve, which produces more output persistence.

17. A number of economies have recently experienced much less of a cyclical downturn than the euro area. If, indeed, euro-area activity is more vulnerable to shocks than is the case elsewhere, the costs of weak transmission channels for monetary policy could be particularly high. However, evidence of greater vulnerability in the euro area does not abound and received wisdom points to greater "bounciness" of the US economy. 
account for greater structural rigidities in product and labour markets. With the incorporation of these changes, the resulting dynamics are within the range of the ECB's Area-Wide Model used to describe the euro-area economy (Table 6). In particular, inflation is less affected by policy actions and sacrifice ratios are correspondingly higher, as would be expected in economies with greater product and labour market rigidities.

19. The introduction of these rigidities into the model reduces the amplitude of the cycle arising from a negative demand shock in an economy with a bank-lending channel, resulting in a more drawn-out adjustment of output back towards equilibrium (Figure 7). The unemployment rate now has a higher peak and takes longer to get back towards equilibrium. Not incorporated into the model are any hysteresis effects. Such effects are generally associated with the same kind of structural policy settings that create rigidities in wage, price and employment adjustment. If hysteresis effects were present, output and employment would look considerably worse than shown here.

20. The monetary policy response also differs noticeably compared with that shown in the previous two simulations. Reflecting the stickiness of wages and prices, the monetary authorities do not reduce nominal interest rates as much and real interest rates fall by less than they did in the simulations discussed above. At the same time, real interest rates have to remain lower for a longer period of time in order to get the economy heading back towards equilibrium.

\section{Sensitivity tests concerning the policy rule and the type of shock}

21. In the simulations above, the rule adopted by the monetary authorities was identical in the models replicating the US and the euro-area economies. It could, however, be argued that monetary policy should be more activist in an economy with a weaker transmission channel. To test the importance of this argument the weight on inflation in the policy rule was doubled on the policy rule in the euro-area model. The results of this exercise can be seen in Figure 8. Although real interest rates fall further, the impact on the real variables (output, consumption and investment) is limited. Thus, a modestly more aggressive policy approach might make little impact on the real economy, given the strong effects of rigidities in labour and product markets. Indeed, model simulation results suggest that a very aggressive response (the weight on inflation is increased 6 times) would need to be adopted in order to deliver similar real-side outcomes to those of the US-model. Such a response, however, does not take into account the potential costs that interest rate volatility may have on the real economy, and lie well outside the range of historical policy reactions (Figure 9).

22. Another sensitivity test is to investigate to what extent the better performance of the model of the US economy is conditioned on the demand shock examined. This is looked at in a limited sense by exposing the models to two common supply-side shocks: ${ }^{18}$ a cost-push (wage) shock and a relative price (exchange rate) shock. Figure 10 presents the implied "losses" for the euro-area model relative to the US model under differing weights on inflation in the loss functions (for both economies). ${ }^{19}$ Whatever the weight used, losses are larger in the euro-area model than in the US model when exposed to the two shocks. Furthermore, the bigger the weight on inflation, the greater is the loss in the euro-area model. The economic intuition behind this is that when faced with a supply shock the euro area takes much longer to adjust back because of the rigidities in wages and prices. For a demand shock, losses are also higher unless a very significant weight is placed on inflation.

18. A full-blown stochastic simulation analysis would provide a better test of sensitivity to the type of shock, but is outside the scope of this paper.

19. The loss functions are defined as the present value of the sum of deviations in output and inflation from equilibrium. 


\section{Some policy implications}

23. To the extent the stylised models considered in this paper capture the broad workings of the US and euro-area economies, the findings suggest some policy implications. To begin with, labour and product market rigidities appear to be key in reconciling differences in response patterns between the US and euro-area economies with what is known about how each responds to a demand shock, but as well in shaping the monetary policy response.

- When product and labour markets are flexible, policy rates have to fall significantly in response to a negative demand shock. Perhaps not surprisingly, policy has to do even more initially when there are impediments to the functioning of financial markets. At the same time, policy has to be just as flexible when it comes to withdrawing stimulus. In the case of a bank-lending channel exerting a strong influence, real rates, once they start to rise, have to move even more quickly, and by a larger amount from their trough, in order to contain inflation.

- On the other hand, in the face of an inflexible economy, characterised by sluggish wage and price adjustment, the cycle is damped, particularly for inflation. Accordingly, the required policy response is initially muted, even in the presence of a number of imperfections in the monetary transmission mechanism. Subsequently, because the rebound in inflation is also sluggish, low real interest rates, once established, have to be maintained for longer in order to facilitate adjustment, regardless of the characteristics of the transmission mechanism.

- The above conclusion is based on simulations which assume that each central bank has the same reaction function (i.e. identical weights in the forward-looking Taylor rule). If, however, the central bank in the inflexible economy placed a greater weight on inflation than did the one in the flexible economy, real rates would initially respond by more. However, they would also remain lower for longer as suggested above. Even with a moderately more aggressive policy approach, the real-side gains appear limited given product and labour market rigidities.

- If it were assumed that the central bank in the inflexible economy aimed for a similar outcome for output as that in the stylised US model, real interest rates would have to fall by much more and interest rate volatility would likely entail significant costs. This highlights the important role product and labour market rigidities play in the model.

- Finally, improving the functioning of financial markets and the transmission mechanism would bring about significant gains. Specifically, a more diversified financial system, particularly one that is less bank dependent, may help an economy to adjust faster following a shock. Such efforts would complement reforms aimed at improving the functioning of labour and product markets. 


\section{APPENDIX: POLICY TRANSMISSION AND MODEL EQUATIONS}

\section{A.I. Introduction}

24. In this Appendix some key parameterisations of the models used in the main text are discussed. The first section outlines the equations that determine consumption and investment expenditures, while the second section is concerned with the modelling of price and wage-setting and the short-run demand for labour. The parameterisations are summarised in Table A1 where the coefficients are expressed relative to the model of the US economy. For example, the first row reports the sum of the coefficients on real interest rates in consumption expenditures. The value of 0.5 for the economy with weaker policy transmission implies that the coefficients are half the value of the US economy model. Also reported are maximum lag lengths in the equations and other factors leading to the differing responses seen in the main paper.

\section{A.II. Consumption and investment expenditures}

25. In the model, changes in short-term interest rates affect consumption, investment and net exports, the latter via the impact of policy changes on the real exchange rate. In this paper the focus is on how differences in the transmission mechanism may affect domestic investment and consumption expenditures only, although movements in the exchange rate may have differential impacts on aggregate demand in the United States and the euro area. ${ }^{20}$

26. The short-term evolution of consumption is affected by the deviation of real interest rates from their assumed neutral rate levels and the deviations of financial asset stocks from their equilibrium positions as follows:

$$
\text { (A1) } c=c^{*}-\omega_{1} L\left(r-r^{*}\right)-\omega_{2} L\left(r l-r l^{*}\right)+\omega_{3}(f a-f a *)
$$

where $c$ is consumption, $r$ is the 90 -day real interest rate, $r l$ is the five-year real interest rate ${ }^{21}, f a$ is the ratio of financial assets to GDP, starred variables represent the equilibrium levels of these variables, and $L$ is a lag operator.

20. As the euro area is more open to the rest of the world than the United States (on a gross trade basis) it might be expected that sustained changes in the exchange rate have a larger impact on demand. However, at least over the short run, the so-called indirect channel of the exchange rate may be blunted in the euro area due to the presence of relatively higher levels of product and labour market regulation and/or resource immobility, hampering the reallocation of resources between the domestic and externally focused sectors of the economy.

21. Real rates are defined as nominal interest rates less the model-consistent expectations of inflation. 
ECO/WKP(2004)5

Table A1. Parameterisation of the models

\begin{tabular}{|c|c|c|c|c|}
\hline & \multicolumn{4}{|c|}{ Models } \\
\hline & $\begin{array}{l}\text { US Economy } \\
\text { (1) }\end{array}$ & $\begin{array}{c}\text { With } \\
\text { weaker policy } \\
\text { transmission } \\
\text { (2) }\end{array}$ & $\begin{array}{c}\text { With } \\
\text { bank lending } \\
\text { channel } \\
\text { (3) }\end{array}$ & $\begin{array}{c}\text { Euro area } \\
(4)\end{array}$ \\
\hline \multicolumn{5}{|l|}{ Parameterisation of consumption and investment } \\
\hline Weight on real interest rate deviations $\left(\omega_{1}\right.$ and $\left.\omega_{2}\right)$ & 1 & 0.5 & 0.5 & 0.5 \\
\hline Lag-length of interest rates in consumption ${ }^{a}$ & 4 & 6 & 6 & 6 \\
\hline Weight on financial asset deviations $\left(\omega_{3}\right)$ & 1 & 0.4 & 0.4 & 0.4 \\
\hline Lag-length of financial assets in consumption & 2 & 4 & 4 & 4 \\
\hline \multicolumn{5}{|l|}{ Aggregate capital accumulation ${ }^{b}$} \\
\hline Weight on real interest rate deviations ( $\kappa_{1}$ an $\left.\kappa_{2}\right)$ & 1 & 0.8 & 0.8 & 0.8 \\
\hline Lag-length of interest rates in capital formation & 4 & 6 & 6 & 6 \\
\hline Discount parameter on capital adjustment costs $(\varsigma)$ & 1 & 1 & 1.25 & 1.25 \\
\hline Aggregate weight on capital adjustment costs $\left(\operatorname{sum}\left(\varphi_{i}\right)\right)$ & 1 & 1 & 1.75 & 1.75 \\
\hline \multicolumn{5}{|l|}{ Small firm capital accumulation ${ }^{c}$} \\
\hline Weight on real interest rate deviations ( $K_{1 s}$ and $\left.K_{2 s}\right)$ & n.a & n.a & 0.8 & 0.8 \\
\hline Lag-length of interest rates in capital formation & n.a & n.a & 6 & 6 \\
\hline Discount parameter on capital adjustment costs $(\varsigma)$ & n.a & n.a & 2 & 2 \\
\hline Aggregate weight on capital adjustment costs $\left(\operatorname{sum}\left(\varphi_{i}\right)\right)$ & n.a & n.a & 4 & 4 \\
\hline \multicolumn{5}{|l|}{ Large firm capital accumulation } \\
\hline Weight on real interest rate deviations ( $K_{1 /}$ and $\left.\kappa_{21}\right)$ & n.a & n.a & 0.8 & 0.8 \\
\hline Lag-length of interest rates in capital formation & n.a & n.a & 6 & 6 \\
\hline Discount parameter on capital adjustment costs $(\varsigma)$ & n.a & n.a & 1 & 1 \\
\hline Aggregate weight on capital adjustment costs $\left(\operatorname{sum}\left(\varphi_{i}\right)\right)$ & n.a & n.a & 1 & 1 \\
\hline \multicolumn{5}{|l|}{ Parameterisation of prices, wages and labour demand } \\
\hline \multicolumn{5}{|l|}{ Price setting curve } \\
\hline Price flexibility $\left(\beta_{1}\right)$ & 1 & 1 & 1 & 0.6 \\
\hline Labour adjustment costs $\left(\beta_{11}\right)$ & 1 & 1 & 1 & 2 \\
\hline Price adjustment to wages $\left(\beta_{2}\right)$ & & & & 1.2 \\
\hline Lag length in prices & 2 & 2 & 2 & 4 \\
\hline \multicolumn{5}{|l|}{ Wage setting curve } \\
\hline Real wage flexibility $\left(\gamma_{1}\right)$ & 1 & 1 & 1 & 0.6 \\
\hline Wage adjustment to prices $\left(\gamma_{2}\right)$ & 1 & 1 & 1 & 1.7 \\
\hline Lag length in wages & 2 & 2 & 2 & 4 \\
\hline \multicolumn{5}{|l|}{ Short-run labour demand } \\
\hline Okun's law coefficient $\left(\delta_{1}\right)$ & 1 & 1 & 1 & 0.8 \\
\hline Lag length in Okun's law & 2 & 2 & 2 & 4 \\
\hline Weight on lagged gap $\left(\delta_{2}\right)$ & 1 & 1 & 1 & 3.3 \\
\hline
\end{tabular}

a) The lag lengths reported are the maximum and in quarters.

b) The aggregate capital stock parameters for models (3) and (4) are calculated by aggregating the small and large capital stock parameters using the assumed small and large firm weights in the aggregate capital stock (i.e. 0.25:1).

c) Not applicable.

Source: OECD. 
27. The calibration of the coefficients $\omega_{1}$ and $\omega_{2}$ was decided such that the US and euro-area models delivered reasonably similar profiles for consumption following a monetary policy shock, as presented in the main text. Across all models examined, the weight on short-term real interest rate deviations was set at one-and-a-half times the weight on long rate deviations, although, in principle, this may well be another source of differing policy transmission between the United States and the euro area. To reflect differing transmission speeds of policy rates through to retail rates (HM Treasury, 2003) alternative lag lengths are imposed. In particular, the mean lag length in the US economy is set at two-quarters while it is around four-quarters in the economies with weaker policy transmission. This is a rather narrow difference compared with some historical estimates, but it is consistent with recent evidence ${ }^{22}$ that transmission speeds appear to be increasing in the euro-area economies.

28. The calibration of $\omega_{3}$ is based on recent studies of consumption patterns in the $\mathrm{G} 7$ economies (Boone et al., 2001, and Edison and Sløk, 2002). Although the equations estimated in these studies are not strictly comparable to the form of (A1) above, it is found that changes in wealth in the US economy can have over twice the impact on the short-term evolution of consumption relative to euro-area economies and the estimated lags are around two quarters to a year longer. Reflecting this evidence, the coefficient on $\omega_{3}$ is set at around 0.4 of the US value for the economies with weaker policy transmission and the lag length is also two quarters longer.

29. Investment expenditures are derived from a standard capital accumulation equation. The evolution of the capital stock around its desired level is modelled as:

$$
\mathrm{k}=\mathrm{k}^{*}+\kappa_{1} \mathrm{~L}(\Delta \mathrm{y})-\kappa_{2} \mathrm{~L}(\mathrm{r}-\mathrm{r} *)-\kappa_{3} \mathrm{~L}\left(\mathrm{rl}-\mathrm{rl}{ }^{*}\right)-\mathrm{kadj}
$$

where $\mathrm{k}$ is the capital stock, $\mathrm{y}$ is output, $\mathrm{r}$ and $\mathrm{rl}$ is the short and long-term interest rate, kadj represents short-term capital adjustment costs, starred variables represent the equilibrium levels of the variables and $L$ is a lag operator. Equation (A2) is used for the US economy model and the model where policy transmission is weaker. For the economy where a bank lending channel is posited the aggregate capital stock is spit into two sub-stocks:

$$
\begin{aligned}
& \mathrm{ks}=\mathrm{ks} *+\kappa 1 \mathrm{~L}(\Delta \mathrm{y})-\kappa 2 \mathrm{sL}(\mathrm{r}-\mathrm{r} *)-\kappa 3 \mathrm{sL}\left(\mathrm{rl}-\mathrm{rl}{ }^{*}\right)-\mathrm{ksadj} \\
& \mathrm{kl}=\mathrm{k} l^{*}+\kappa 1 \mathrm{~L}(\Delta \mathrm{y})-\kappa 2 \mathrm{lL}(\mathrm{r}-\mathrm{r} *)-\kappa 3 \mathrm{lL}\left(\mathrm{rl}-\mathrm{rl} \mathrm{l}^{*}\right)-\mathrm{kladj} \\
& \mathrm{k}=\mathrm{ks}+\mathrm{kl}
\end{aligned}
$$

where ks is the capital stock for small firms and $\mathrm{kl}$ is the stock for large firms.

30. In the paper, as in most estimated models of capital formation, the investment accelerator parameter, $\kappa_{1}$, is the dominant influence on short-run capital formation. It is calibrated to deliver peak investment responses of around twice the peak response in output for a temporary shock, which is around the average of accelerator effects in G7 economies estimated in Turner et al., (1996). The accelerator is assumed to have the same impact across all models and capital stocks. The impact of interest rates on the capital stock are relatively small and the coefficients are kept fairly similar across the model economies, reflecting results from both VAR and structural model simulations presented in Angeloni et al., (2003a). The mean lag length on interest rates in capital formation is, however, slightly shorter for the US model.

31. The most important factor behind the differences in investment responses in the main paper is differences in adjustment costs. Following Pesaran (1991) and Tinsley (1993), capital adjustment costs are

22. See de Bondt (2002). 
specified as a cost function that balances the loss from being away from equilibrium against the cost of adjusting to the equilibrium path: ${ }^{23}$

$$
\operatorname{kadj}=\mathrm{E}\left[\sum_{\tau=0}^{\infty} \varsigma\left(k_{t+\tau}-k^{*}{ }_{t+\tau}\right)^{2}+\sum_{i=0}^{n} \phi_{i}\left((1-L)^{i} k_{t+\tau}\right)^{2}\right]
$$

32. The first term in the cost function penalises the deviation of capital from its equilibrium position at time $t+\tau$, subject to a discount, $\varsigma$, on the expected deviations. The second term penalises changes in the $i$ th difference of the capital stock. The higher the order of the lag operator, L, and the greater the weight placed on the changes, $\varphi$, the more gradual the adjustment will tend to be. In the US model economy, the cost function is tilted towards penalising deviation from the equilibrium path more heavily. Consequently, adjustment of the capital stock and investment flows occur more quickly. In the economy with a bank lending channel and the euro-area economy, relatively more weight is placed on the loss arising from adjusting the capital stock from its present position and there is higher discounting of the deviation in the expected evolution in capital from its equilibrium level, particularly for the capital stocks representing small firms (Table A1, columns 3 and 4).

\section{A.III. Parameterisation of price and wage formation and short-run labour demand}

33. The modelling of price and wage formation in the models is based on the framework developed in Layard et al., (1991), and the equations are specified in a form similar to Turner et al., (1996) as follows:

$$
\begin{aligned}
& \Delta \mathrm{p}=\alpha_{1} \mathrm{~L}(\Delta \mathrm{p})+\left(1-\alpha_{1}\right) \mathrm{E}(\Delta \mathrm{p})+\beta_{1} \text { ygap }-\beta_{2} \Delta \Delta \mathrm{w}-\lambda \Delta \mathrm{u}-\beta_{3}\left(\mathrm{p}(-1)-\mathrm{w}(-1)+\mathrm{q}^{*}(-1)\right) \\
& \mathrm{E}(\Delta \mathrm{p})=\alpha 2 \mathrm{~L}(\Delta \mathrm{p})+\alpha 3 \mathrm{~F}(\Delta \mathrm{p})+(1-\alpha 2-\alpha 3) \Delta \mathrm{p}^{*} \\
& \Delta(\mathrm{w}-\mathrm{p})=\mathrm{L}(\Delta(\mathrm{w}-\mathrm{p}))-\gamma_{1} \text { ugap }-\gamma_{2}(\Delta \Delta \mathrm{p})-\gamma_{3}\left(\mathrm{w}(-1)-\mathrm{p}(-1)-\mathrm{q}^{*}(-1)\right)+\gamma_{4} \mathrm{~L}(\Delta \mathrm{cpi}-\Delta \mathrm{p})
\end{aligned}
$$

where $\Delta$ is the first difference operator, $\mathrm{L}$ is a lag operator (where the weights placed on the lags sum to 1 ) $\mathrm{p}$ is the domestic price level, $\mathrm{w}$ is nominal wage level, $\mathrm{q}^{*}$ is an exogenously set level of trend labour productivity, $\mathrm{u}$ is the unemployment rate, ygap is the output gap, ugap is the unemployment gap, $\mathrm{z}$ is the real exchange rate and cpi is the consumer price index. All variables are expressed in a logarithmic form. $\mathrm{E}(\Delta \mathrm{p})$ are expectations of the change in prices, $\mathrm{F}($.$) is a forward-shift operator (with the sum of the weights$ placed on the forecast leads equal to 1$), \Delta \mathrm{p}^{*}$ is the monetary authorities' target rate of inflation and $\Delta \mathrm{q}^{*}$ is trend labour productivity growth.

34. Equations A7 to A9 describe the interaction between price and wage-setting behaviours. In equilibrium the price level is set equal to marginal labour costs, w-q, and real wages equal productivity, q. In the short run, prices and wages differ due to the presence of parameters designed to capture both real and nominal rigidities. In particular, real rigidities are higher the smaller the weight is on the gap terms ( $\beta_{1}$ and $\gamma_{1}$ ) and the larger is the value of $\lambda$. As lag lengths increase and greater weight is placed on the acceleration terms $\left(\beta_{2}\right.$ and $\left.\gamma_{2}\right)$ nominal rigidities rise. Also influencing the dynamics of price and wage setting behaviour is the structure of inflation expectations formation (A8). This is specified as a so-called "mixed representation" -- inflation expectations are based on past price changes, expected price changes and the central bank's target inflation rate.

23. See also Black et al., (1996) for a general discussion on the structure of adjustment. 
35. In the US model the weight on the gap terms is relatively large while nominal rigidities are relatively small. In contrast, in the euro-area model nominal rigidities are more pervasive and the weight placed on the gap terms is smaller. Across all models expectations formation is assumed to be the same, although given that nominal rigidities are higher in the euro area, inflation expectations will also effectively depend more on past price changes. Overall, these changes result in a more persistent inflation process for the euro area and a higher sacrifice ratio compared with the United States.

36. The short-run demand for labour in the model is expressed as a simple Okun's law relationship as follows:

$$
\text { ugap }=-\delta_{1} \text { ygap }+\delta_{2} \text { ugap }_{-1}
$$

where ygap is the output gap and ugap is the unemployment gap.

37. Recent studies on Okun's law relationships suggest that reaction of employment to changes in output or the output gap, $\delta_{1}$, have tended to increase, suggesting that labour market reforms have increased the responsiveness of employment to changes in macroeconomic conditions (see Candelon and Hecq, 1998 and Sögner and Stiassny, 2000). However, significant cross-country differences appear to remain, with countries falling into two groups: those, such as the United States, wherein adjustment of employment occurs fairly quickly (four quarters or less) ${ }^{24}$, and those (for example, Germany and Italy) where adjustment takes considerably longer (Candelon and Hecq, 1998). In addition, in countries where adjustment takes longer, estimates of the Okun's law coefficient tend to be lower, suggesting that labour hoarding and/or restrictions on the hiring and firing of labour may initially insulate labour adjustment, but a prolonged period of adjustment is eventually required. ${ }^{25}$ To account for these factors two stylised representations of the Okun's law relationship are calibrated. In the US economy the weight placed on the previous periods' unemployment gap is low, the output gap affects the unemployment gap with a twoquarter lag and the weight placed on $\delta_{2}$ is 0.5 , a value that falls within the range of US economy estimates. In the euro-area economy, where the lag length between the output and unemployment gaps is longer, greater weight is placed on $\delta_{2}$ to extend adjustment, while the weight placed on the output gap is lower.

24. In this regard, the present period of relatively weak employment growth in the US economy is an exception.

25. On the other hand, studies that account for possible non-linearities in the Okun's law relationship (in particular, that unemployment increases in downturns are larger than the reduction in unemployment seen in upturns) suggest that the impact of output on unemployment is relatively uniform in a downturn (Harris and Silverstone, 2001). 


\section{REFERENCES}

ANGELONI, I., A.K. KASHYAP, B. MOJON and D. TERLIZZESE (2003a), "Monetary transmission in the euro area: does the interest rate channel explain all?", Paper based on ECB Working Paper, No. 114.

ANGELONI, I., A.K. KASHYAP, B. MOJON and D. TERLIZZESE (2003b), “The output composition puzzle: a difference in the monetary transmission mechanism in the euro area and US", NBER Working Paper Series, No. 9985.

BEAN, C., J. LARSEN and K. NIKOLOV (2002), "Financial frictions and the monetary transmission mechanism: theory, evidence and policy implications", ECB Working Paper Series, No. 113.

BLACK, R., V. CASSINO, A. DREW, E. HANSEN, B. HUNT, D. ROSE and A. SCOTT (1997), “The Forecasting and Policy System: the core model”, Reserve Bank of New Zealand Research Paper, No. 43.

BOONE, L., N. GIROUARD and I. WANNER (2001), "Financial market liberalisation, wealth and consumption", OECD Economics Department Working Papers, No. 308.

CANDELON, B. and A. HECQ (1998), "Stability of Okun's law in a codependent system", IRES Discussion Paper, No. 9816.

CHATELAIN, J.B., A. GENERALE, I. HERNANDO, U. VON KALCKREUTH and P. VERMEULEN (2001), "Firm investment and monetary transmission in the Euro area", ECB Working Papers Series, No. 112.

DALSGAARD, T., C. ANDRÉ and P. RICHARDSON (2001), "Standard shocks in the OECD Interlink model", OECD Economics Department Working Papers, No. 306.

DALSGAARD, T., J. ELMESKOV and C-Y. PARK (2002), "Ongoing changes in the business cycle - evidence and causes”, OECD Economics Department Working Papers, No. 315.

DE BONDT, G. (1998), "Credit channels in Europe: bank level panel data analyses", De Nederlandsche Bank NV Economic Research and Special Studies Department Research Memorandum WO\&E, No. 543/9813.

DE BONDT, G. (1999), “Credit channels and consumption in Europe: empirical evidence”, BIS Working Papers, No. 69.

DE BONDT, G. (2002), "Retail bank interest rate pass-through: new evidence at the euro-area level”, ECB Working Paper Series, No. 136.

EDISON, H. and T. SLØK (2002), "Stock market wealth effect and the new economy: a cross-country study", International Finance, Vol. 5, No. 1.

FARUQUEE, H. (2003) "Exchange rate pass-through and external adjustment in the euro area", in IMF Euro Area Policies (Selected Issues), pp. 48-71, August.

HARRIS, R. and B. SILVERSTONE (2001), “Testing for asymmetry in Okun's law: a cross-country comparison”, Economics Bulletin, Vol. 5, No. 2.

HM TREASURY (2003), EMU and the monetary transmission mechanism.

HUBBARD, R.G. (1998), “Capital-market imperfections and investment”, Journal of Economic Literature, Vol. 36.

JUDD, J.P. and G.D. RUDEBUSCH (1998), “Taylor's Rule and the Fed: 1970-1997”, Federal Reserve Bank of San Francisco Economic Review, No. 3. 


\section{ECO/WKP(2004)5}

KAKES, J. and J-E. STURM (2002), "Monetary policy and bank lending: Evidence from German banking groups, Journal of Banking \& Finance, Vol. 26.

KASHYAP, A.K. and J.C. STEIN (1997), "The role of banks in monetary policy: a survey with implications for the European monetary union", Federal Reserve Bank of Chicago Economic Perspectives, Vol. 22, No. 5.

KASHYAP, A.K. and J.C. STEIN (2000), "What do a million observations on banks say about the transmission of monetary policy?", American Economic Review, Vol. 90, No. 3.

KASHYAP, A.K, J.C. STEIN and D.W. WILCOX (1993), "Monetary policy and credit conditions: evidence from the composition of external finance", American Economic Review, Vol. 83, No. 1.

LAYARD, R., S. NICKELL and P. JACKMAN (1991), Unemployment: macroeconomic performance and the labour market, Oxford University Press, Oxford.

LOUPIAS, C. F. SAVIGNAC and P. SEVESTRE (2001), "Monetary policy and bank lending in France: are there asymmetries?", ECB Working Paper Series, No. 101.

LUDWIG, A. and T. SLØK (2004), "The impact of changes in stock prices and house prices on consumption in OECD countries", Topics in Macroeconomics, forthcoming..

OECD (2002), “Economic Surveys, Euro area”, Vol. 2002/16.

OLINER, S.D. and G.D. RUDEBUSCH (1995), "Is there a bank lending channel for monetary policy?", Federal Reserve Bank of San Francisco Economic Review, No. 2.

OLINER, S.D. and G.D. RUDEBUSCH (1996), “Is there a broad credit channel for monetary policy?”, Federal Reserve Bank of San Francisco Economic Review, No. 1.

PESARAN, M. (1991), “Costly adjustment under rational expectations: a generalization”, Review of Economics and Statistics, No. 73.

SELLON, G. (2002), "The changing US financial system: some implications for the monetary transmission mechanism", Federal Reserve Bank of Kansas City Economic Review, First Quarter.

SÖGNER, L. and A. STIASSNY (2000), “A cross-country study on Okun's law”, Vienna University of Economics and Business Administration Working Paper, No. 13.

TINSLEY, P. (1993), "Fitting both data and theories: polynomial adjustment costs and error-correction decision rules", Finance and Economics Discussion Series 93-21, Board of Governors of the Federal Reserve System, Washington.

TODD, S. (2001), “The effects of securitization on consumer mortgage costs”, Real Estate Economics, Spring.

TURNER, D., P. RICHARDSON and S. RAUFFET (1996), "Modelling the supply side of the seven major OECD economies”, OECD Economics Department Working Papers, No. 167.

WORMS, A. (2001), “The reaction of bank lending to monetary policy measures in Germany", ECB Working Paper Series, No. 96. 


\section{TABLES AND FIGURES}

\section{Table 1. Effects of monetary policy shocks in FRB-US model compared with OECD stylised model}

Deviation from baseline

\begin{tabular}{|c|c|c|c|c|c|c|}
\hline \multirow[b]{2}{*}{ Models } & \multicolumn{3}{|c|}{ FRB-US } & \multicolumn{3}{|c|}{ OECD } \\
\hline & Year 1 & Year 2 & Year 3 & Year 1 & Year 2 & Year 3 \\
\hline \multicolumn{7}{|l|}{ Assumptions } \\
\hline Short-term rate & 1.00 & 1.00 & 0.00 & 1.00 & 1.00 & 0.00 \\
\hline Long-term (10 year) interest rate & 0.16 & 0.06 & 0.00 & 0.16 & 0.06 & 0.00 \\
\hline Effective exchange rate & 1.60 & 0.63 & 0.00 & 1.60 & 0.63 & 0.00 \\
\hline \multicolumn{7}{|l|}{ Effects } \\
\hline CPI & -0.07 & -0.41 & -1.01 & -0.05 & -0.39 & -1.34 \\
\hline GDP & -0.35 & -1.28 & -1.37 & -0.38 & -1.20 & -1.30 \\
\hline \multicolumn{7}{|l|}{ Level } \\
\hline Consumption & -0.37 & -1.35 & -1.44 & -0.49 & -1.41 & -1.46 \\
\hline Investment $^{a}$ & -0.31 & -1.79 & -3.16 & -0.22 & -1.94 & -2.84 \\
\hline Unemployment & 0.12 & 0.66 & 0.77 & 0.07 & 0.43 & 0.68 \\
\hline Memorandum item: sacrifice ratio & & 1.3-1.7 & & & 1.4 & \\
\hline
\end{tabular}

a) Private sector investment.

Source: Angeloni et al., (2003b) and OECD.

Table 2. Differences in financial structure in selected countries, 2001

Data expressed in ratios to GDP (unless noted)

\begin{tabular}{|c|c|c|c|c|c|c|}
\hline & United States & Germany & France & Italy & United Kingdom & Japan \\
\hline \multicolumn{7}{|l|}{ Stock market } \\
\hline Capitalisation $^{a}$ & 1.23 & 0.54 & 0.86 & 0.51 & 1.44 & 0.56 \\
\hline 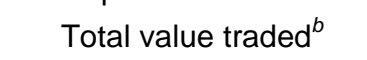 & 2.89 & 0.77 & 0.82 & 0.51 & 1.31 & 0.44 \\
\hline Turnover ratio $^{c}$ & 2.35 & 1.42 & 0.96 & 0.99 & 0.91 & 0.79 \\
\hline \multicolumn{7}{|l|}{ Bond market } \\
\hline Private bond market ${ }^{d}$ & 1.08 & 0.55 & 0.35 & 0.35 & 0.35 & 0.50 \\
\hline Public bond market ${ }^{e}$ & 0.42 & 0.33 & 0.46 & 0.88 & 0.30 & 0.96 \\
\hline Bank credit ${ }^{f}$ & 0.75 & 1.20 & 0.87 & 0.77 & 1.32 & 1.09 \\
\hline
\end{tabular}

a) Value of listed shares to GDP.

b) Total shares traded on the stock market exchange to GDP.

c) Ratio of the value of total shares traded and average real market capitalisation.

d) Private domestic debt securities issued by financial institutions and corporations as a share of GDP.

e) Public domestic debt securities issued by government as a share of GDP.

f) Private credit by deposit money banks to GDP.

Source: World Bank Financial Structure Database. 
Table 3. Securitisation: United States and Europe

\begin{tabular}{|c|c|c|}
\hline & \multicolumn{2}{|c|}{$\begin{array}{c}\text { Share of total bond market } \\
\text { Per cent }\end{array}$} \\
\hline & 31 December 1999 & 30 September 2003 \\
\hline US Treasury & 22.4 & 16.0 \\
\hline Corporate & 20.7 & 20.1 \\
\hline Mortgage-related & 15.6 & 23.6 \\
\hline Money market & 15.6 & 11.6 \\
\hline Municipal & 10.4 & 8.7 \\
\hline Federal agency & 10.2 & 12.2 \\
\hline Asset backed securities & 5.1 & 7.8 \\
\hline \multirow[t]{3}{*}{ Memorandum item: Total market } & $14.7^{a}$ & $21.7^{a}$ \\
\hline & \multicolumn{2}{|c|}{$\begin{array}{c}\text { European securitisation issuance } \\
\text { Billion euros }\end{array}$} \\
\hline & 2000 Q3 & 2003 Q3 \\
\hline Asset-backed securities & 21.9 & 53.0 \\
\hline Mortgage-backed securities & 31.3 & 81.8 \\
\hline
\end{tabular}




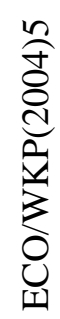

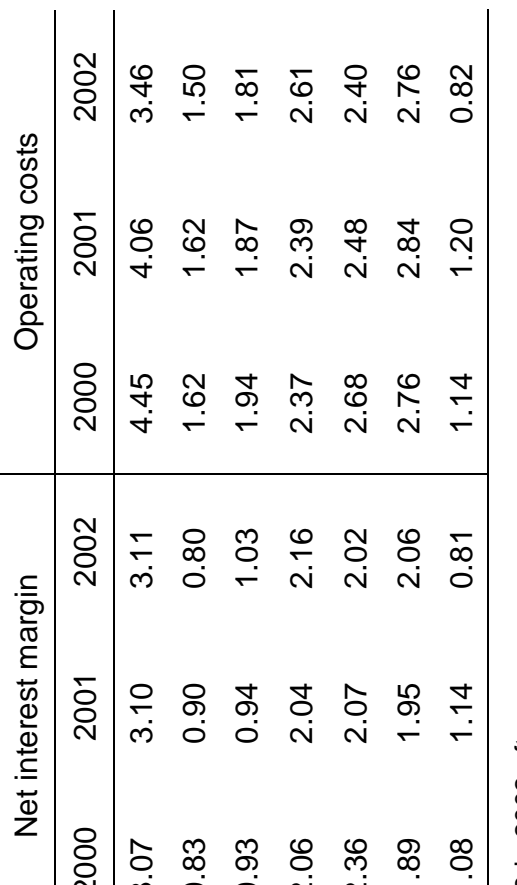

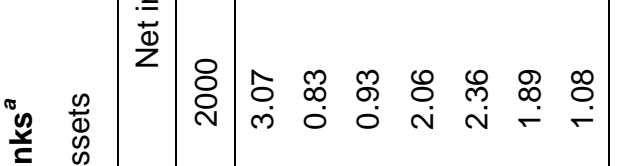

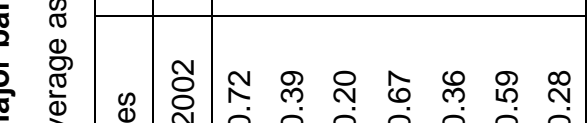

产

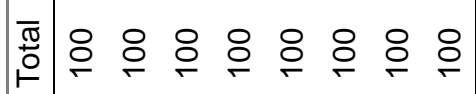

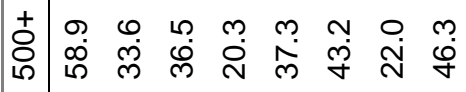

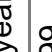

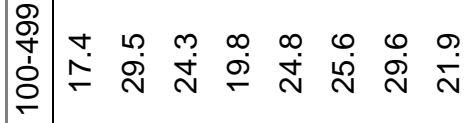

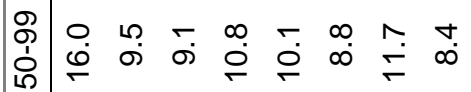

家

$\frac{\sqrt{2}}{\text { ต }}$

政

कு

ㅍّㅁㅇㅇㅁㅇㅇㅇㅇㅇㅇㅇㅇㅇㅇ

㕝

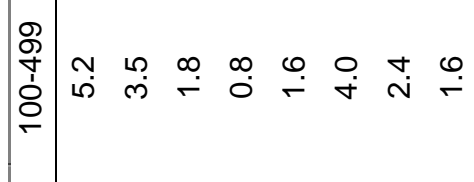

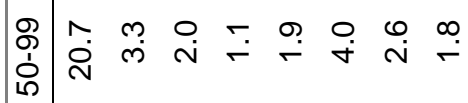
志最

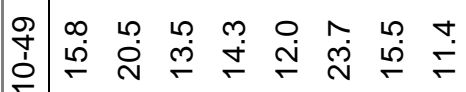

ঠ)

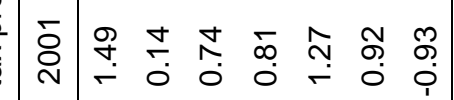

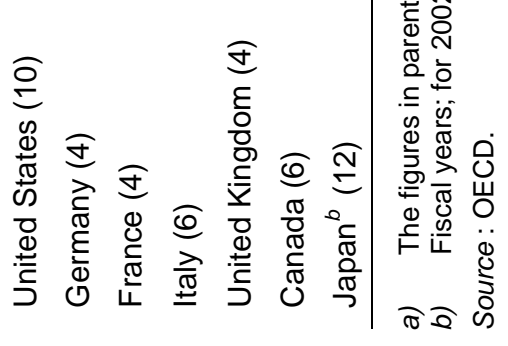

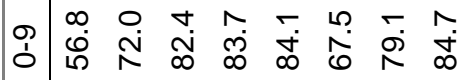

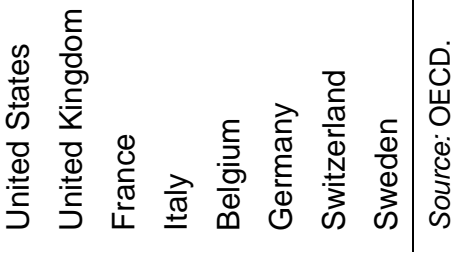


Table 6. Effects of monetary policy shocks in euro-area models compared with the OECD stylised model calibrated to incorporate euro-area features

\begin{tabular}{|c|c|c|c|c|c|c|}
\hline \multirow[b]{2}{*}{ Models } & \multicolumn{3}{|c|}{ Area-wide model (AWM) } & \multicolumn{3}{|c|}{ OECD } \\
\hline & Year 1 & Year 2 & Year 3 & Year 1 & Year 2 & Year 3 \\
\hline \multicolumn{7}{|l|}{ Assumptions } \\
\hline Short-term rate & 1.00 & 1.00 & 0.00 & 1.00 & 1.00 & 1.00 \\
\hline Long-term (10 year) interest rate & 0.16 & 0.06 & 0.00 & 0.16 & 0.06 & 0.00 \\
\hline Effective exchange rate & 1.60 & 0.63 & 0.00 & 1.60 & 0.63 & 0.00 \\
\hline \multicolumn{7}{|l|}{ Effects } \\
\hline $\mathrm{CPI}$ & -0.13 & -0.26 & -0.37 & -0.05 & -0.23 & -0.37 \\
\hline GDP & -0.27 & -0.71 & -0.79 & -0.31 & -0.77 & -0.81 \\
\hline \multicolumn{7}{|l|}{ Level } \\
\hline Consumption & -0.19 & -0.57 & -0.63 & -0.14 & -0.52 & -0.66 \\
\hline Investment $^{a}$ & -0.72 & 2.29 & -2.93 & -0.69 & -2.45 & -2.74 \\
\hline Unemployment & 0.08 & 0.36 & 0.61 & 0.07 & 0.38 & 0.65 \\
\hline Consumption contribution & 0.11 & 0.33 & 0.33 & 0.08 & 0.30 & 0.37 \\
\hline Investment contribution & 0.14 & 0.45 & 0.59 & 0.14 & 0.49 & 0.55 \\
\hline Memorandum item: sacrifice ratio & & $3^{b}$ & & & 3 & \\
\hline
\end{tabular}

a) Total investment.

b) Estimates of sacrifice ratios for the large continental European economies generally average around 3 .

Sources: Angeloni et al., (2003b) and OECD. 
Figure 1. Pass-through of policy rates to market rates

Germany

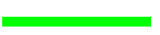

United States

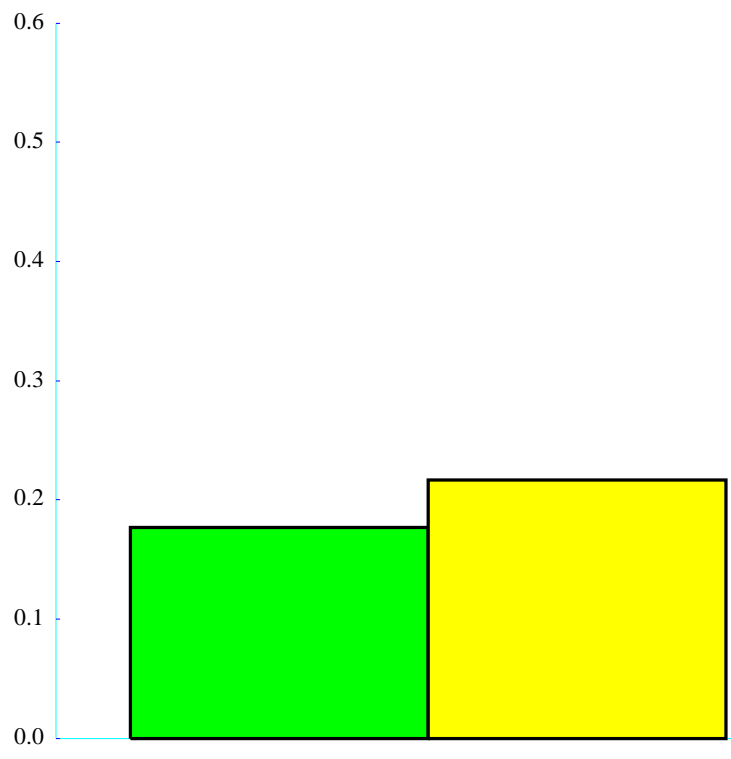

Average 1970-1990

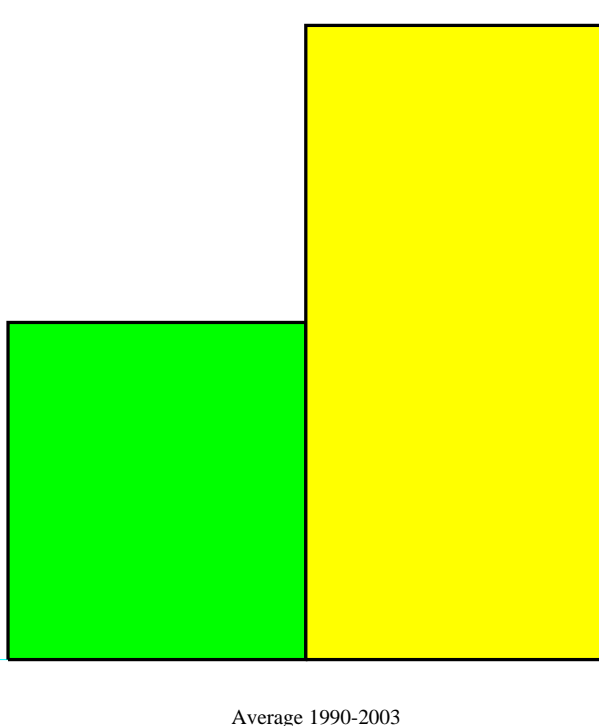

Average 1990-2003

Note: The passthrough was calculated as the average of the ten-year rolling windows (before and after 1990) of the coefficient $\mathrm{x}$ in the change equation in long rates $=$ constant $+\mathrm{x}$ change in policy rates.

The regression was run on monthly data from January 1971 to October 2003.

Also included on the right-hand side were control variables, including lagged left and right-hand side variables, inflation and industrial production. Source: OECD. 
Figure 2. Ratio of gross financial wealth to gross wealth in the household sector

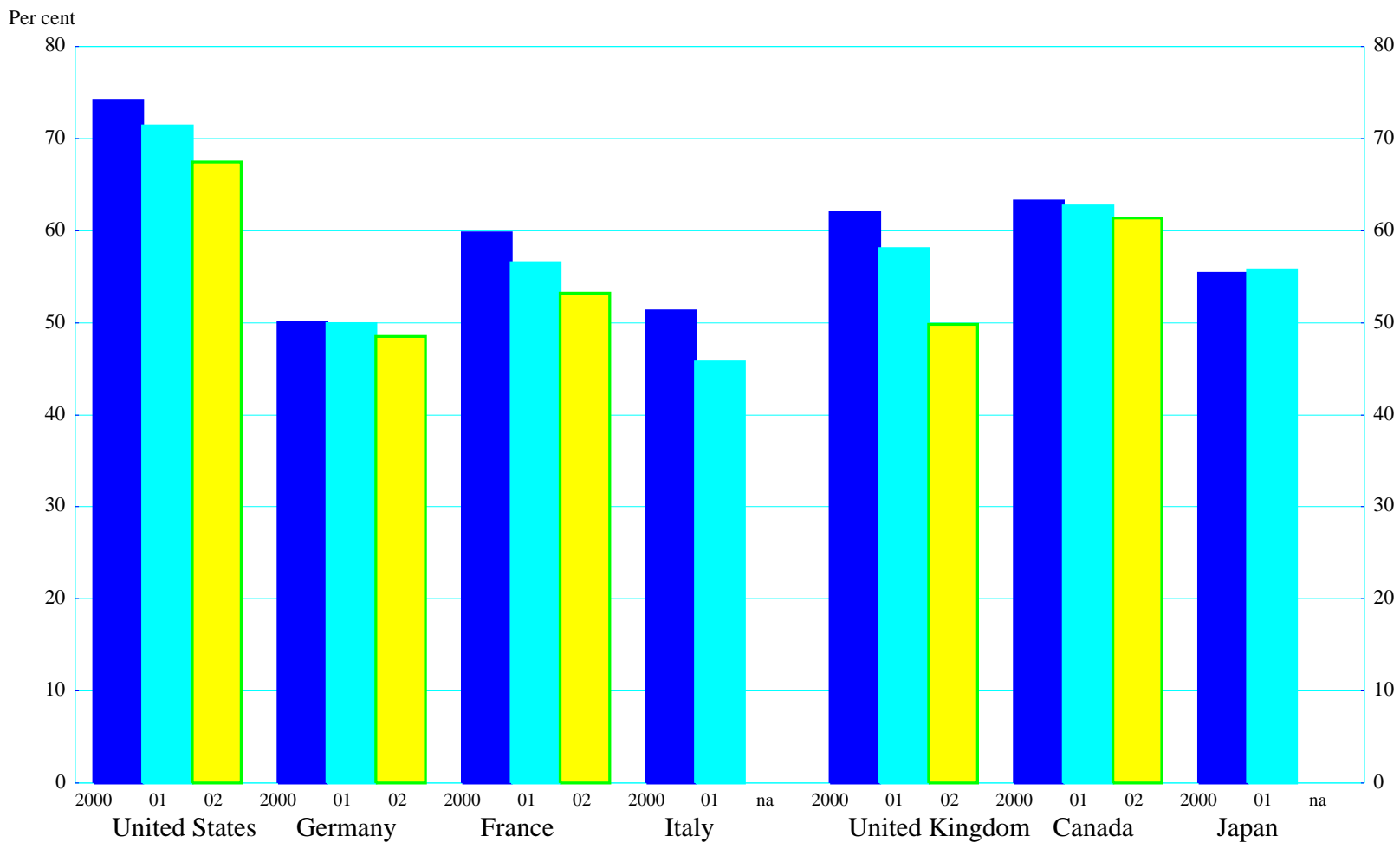

Sources: National sources, OECD. 
Figure 3. The effect of a weaker interest rate channel Per cent deviation from baseline

United States
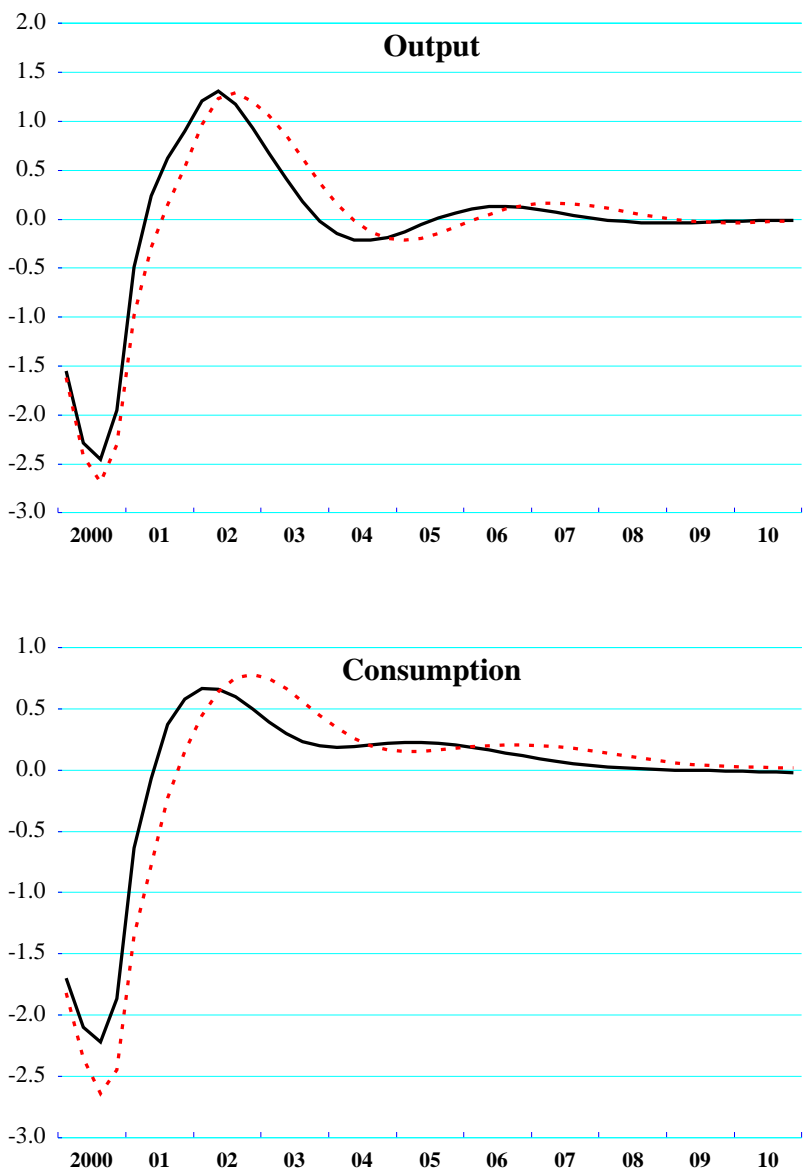

0.5

Price inflation

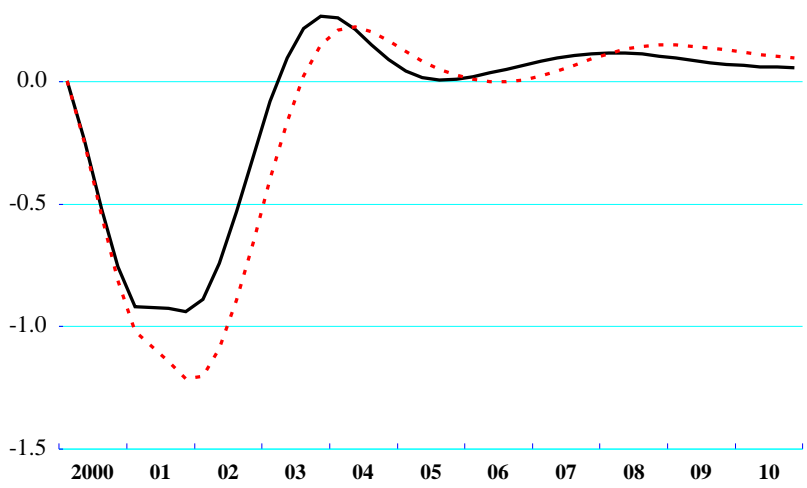

Weaker interest rate channel
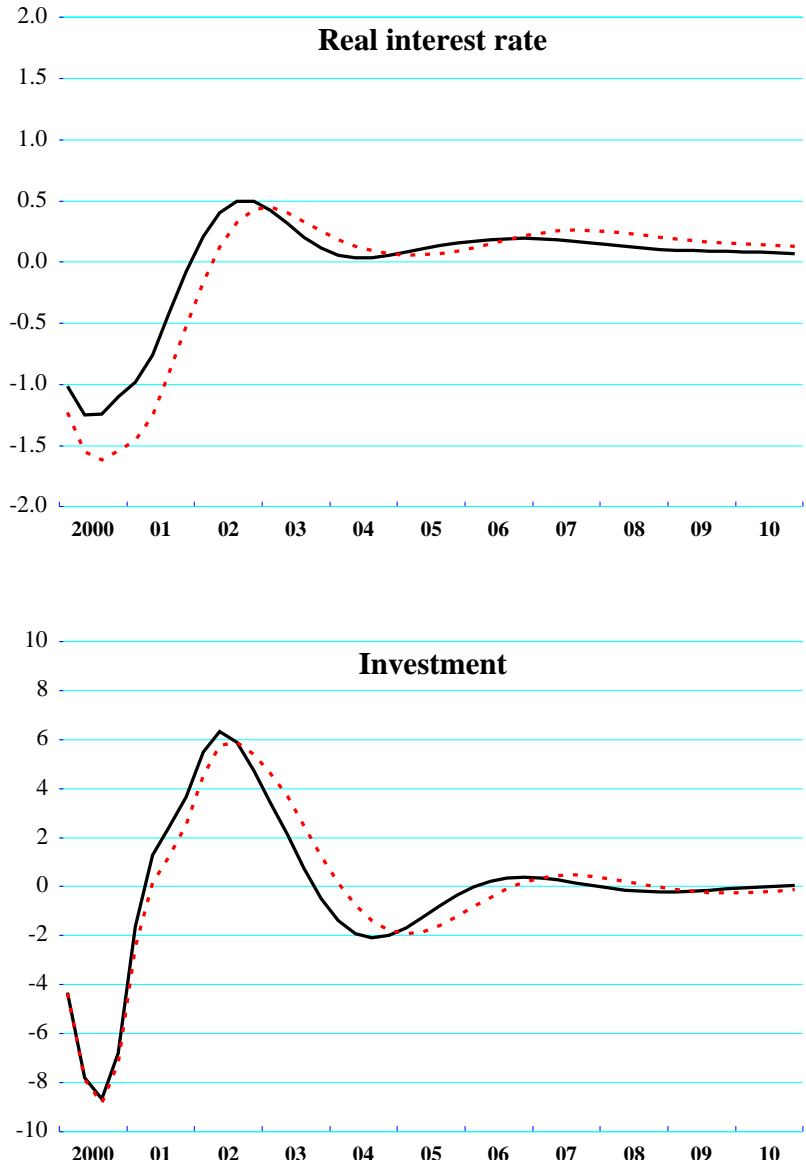

2.0

Unemployment

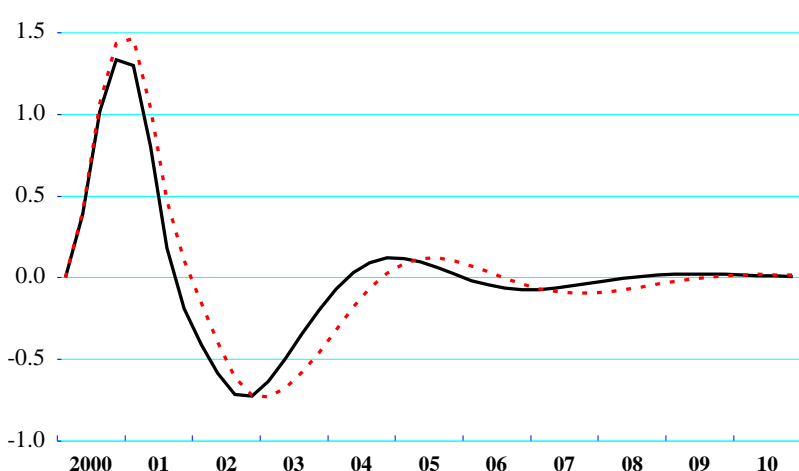

Source : OECD. 
Figure 4. Bank loans as share of GDP

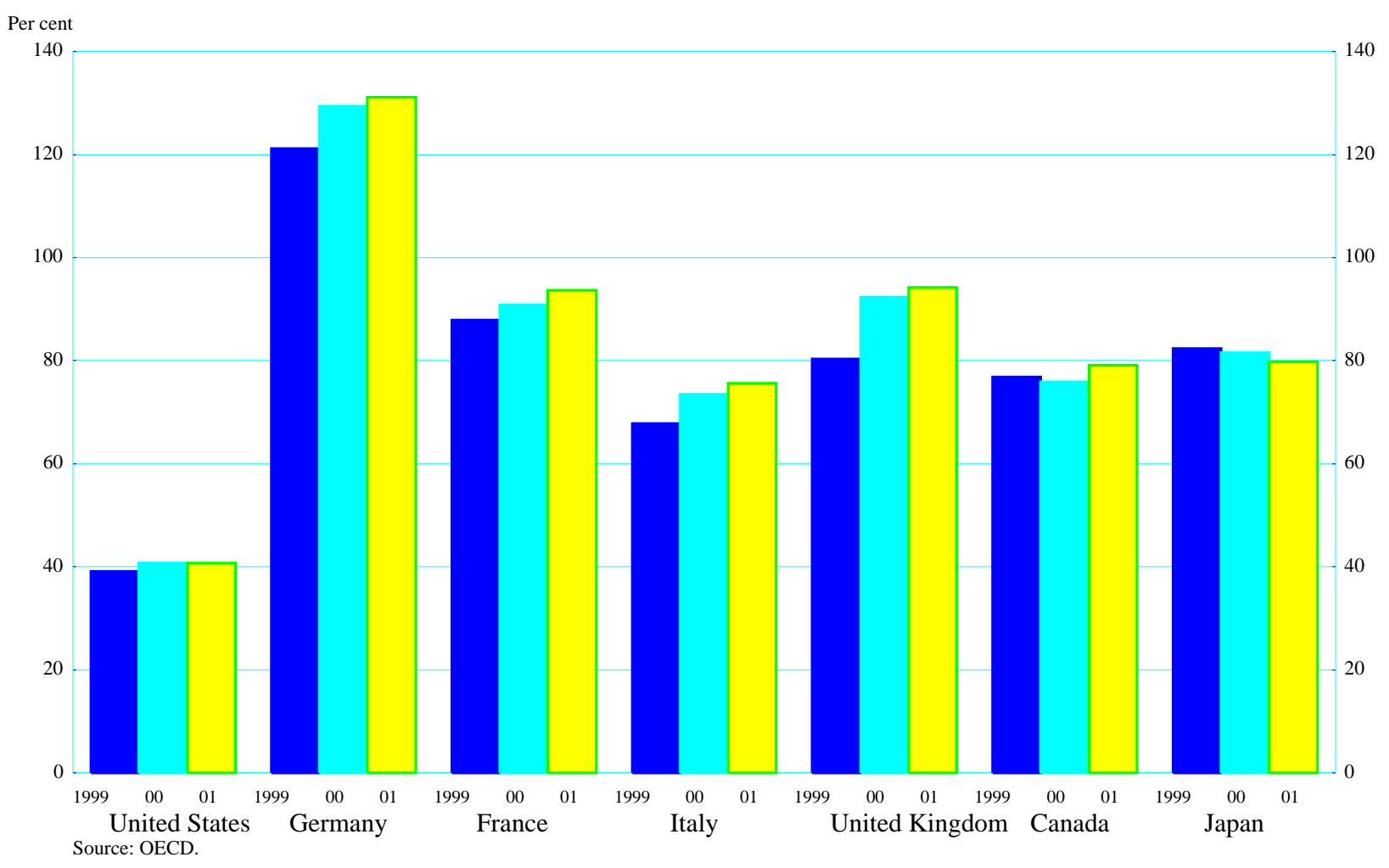


Figure 5. The effect of bank lending and weaker interest rate channels Per cent deviation from baseline
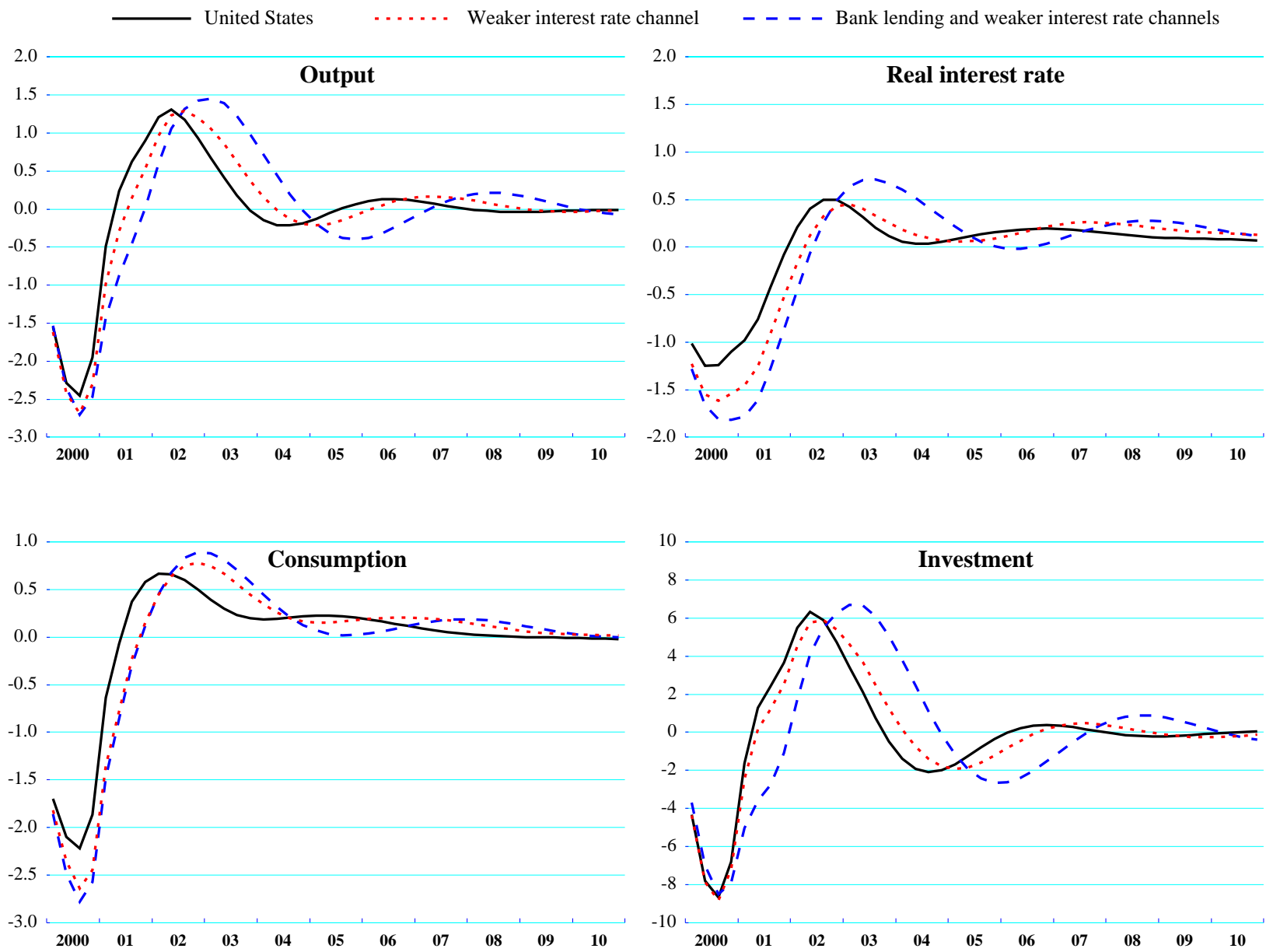

1.0

Price inflation

0.5

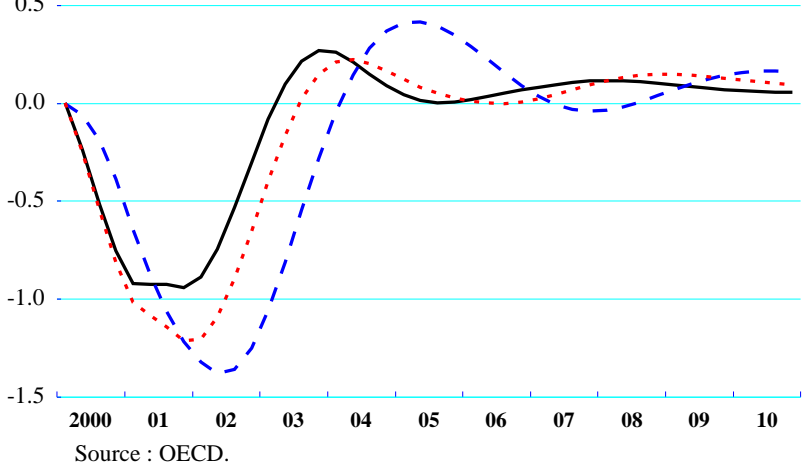

2.0

1.5

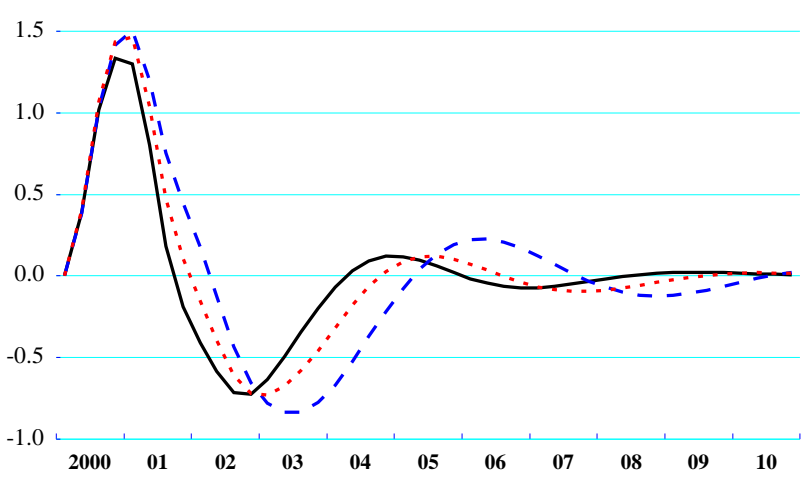


Figure 6. Details of the investment response with bank lending and weaker interest rate channels Per cent deviation from baseline
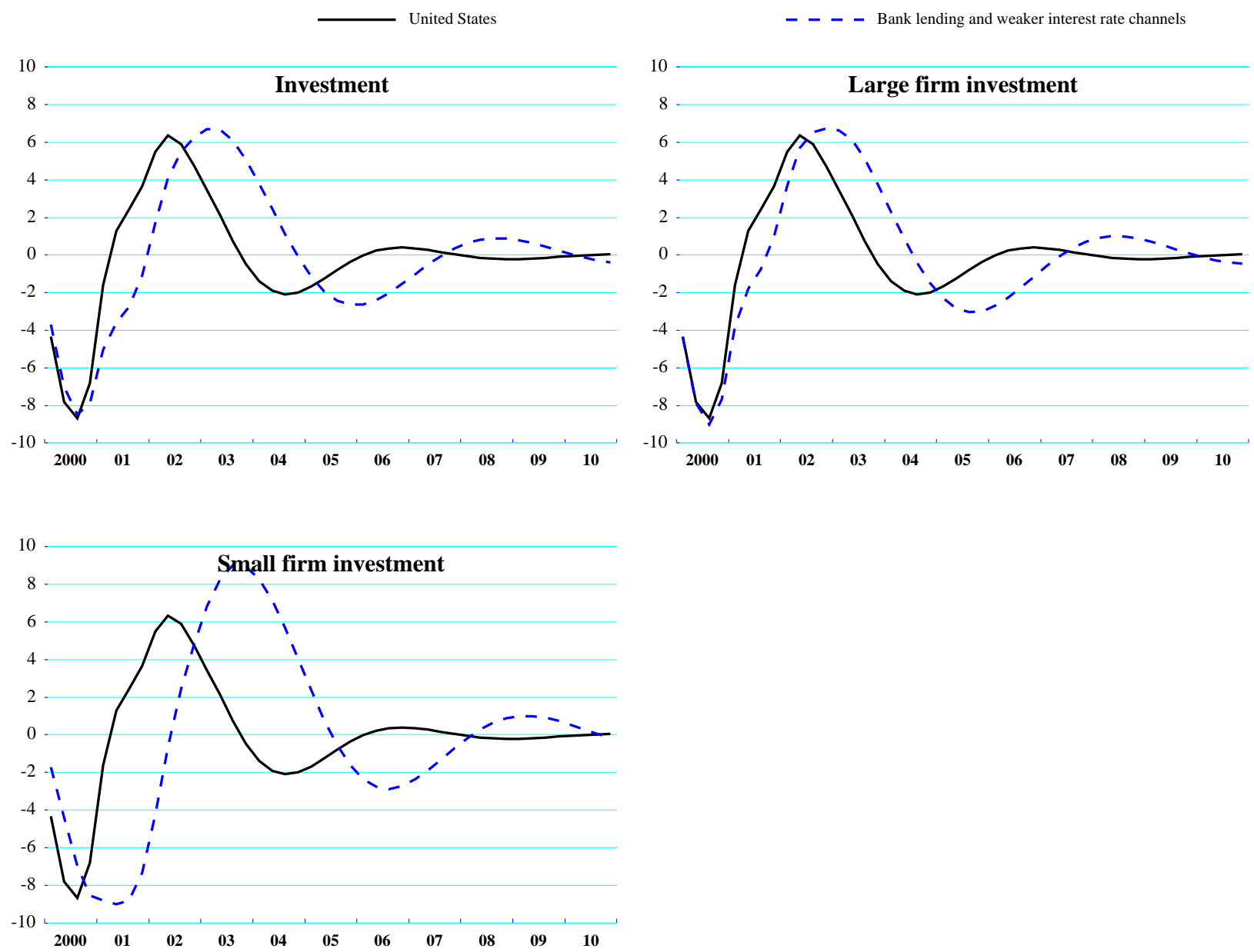

Source : OECD. 
Figure 7. Impact of rigidities and a weaker transmission channel: euro-area versus US model Per cent deviation from baseline
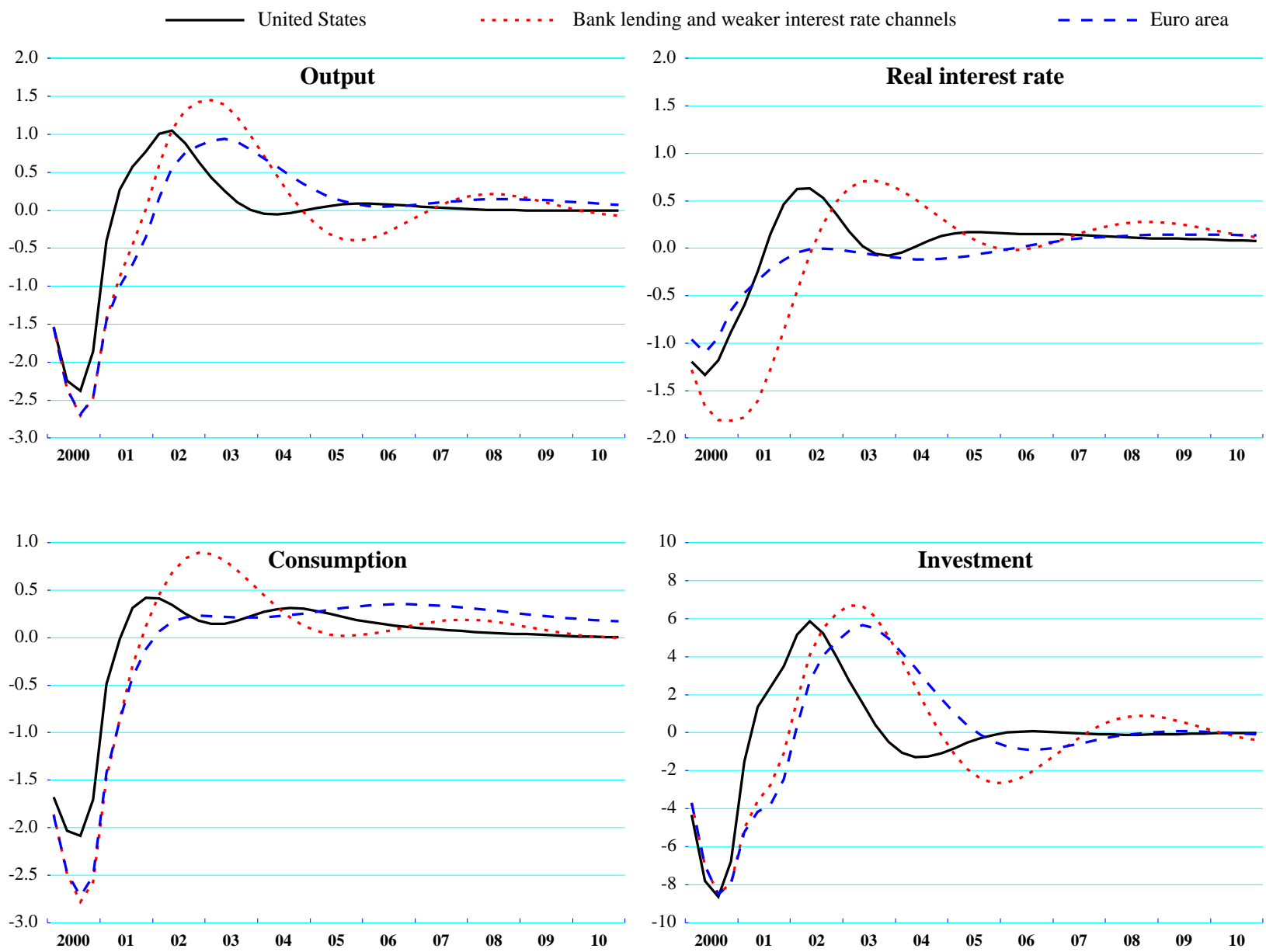

1.0

Price inflation

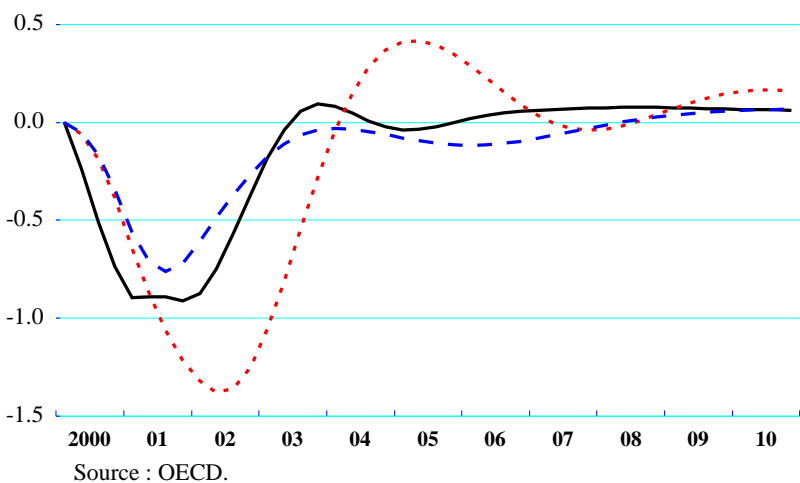

2.0

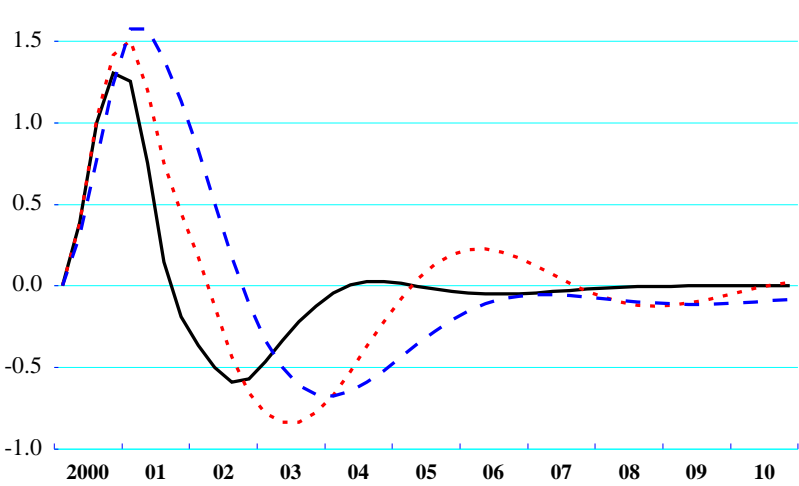


Figure 8. Sensitivity tests : more aggressive policy rule Per cent deviation from baseline
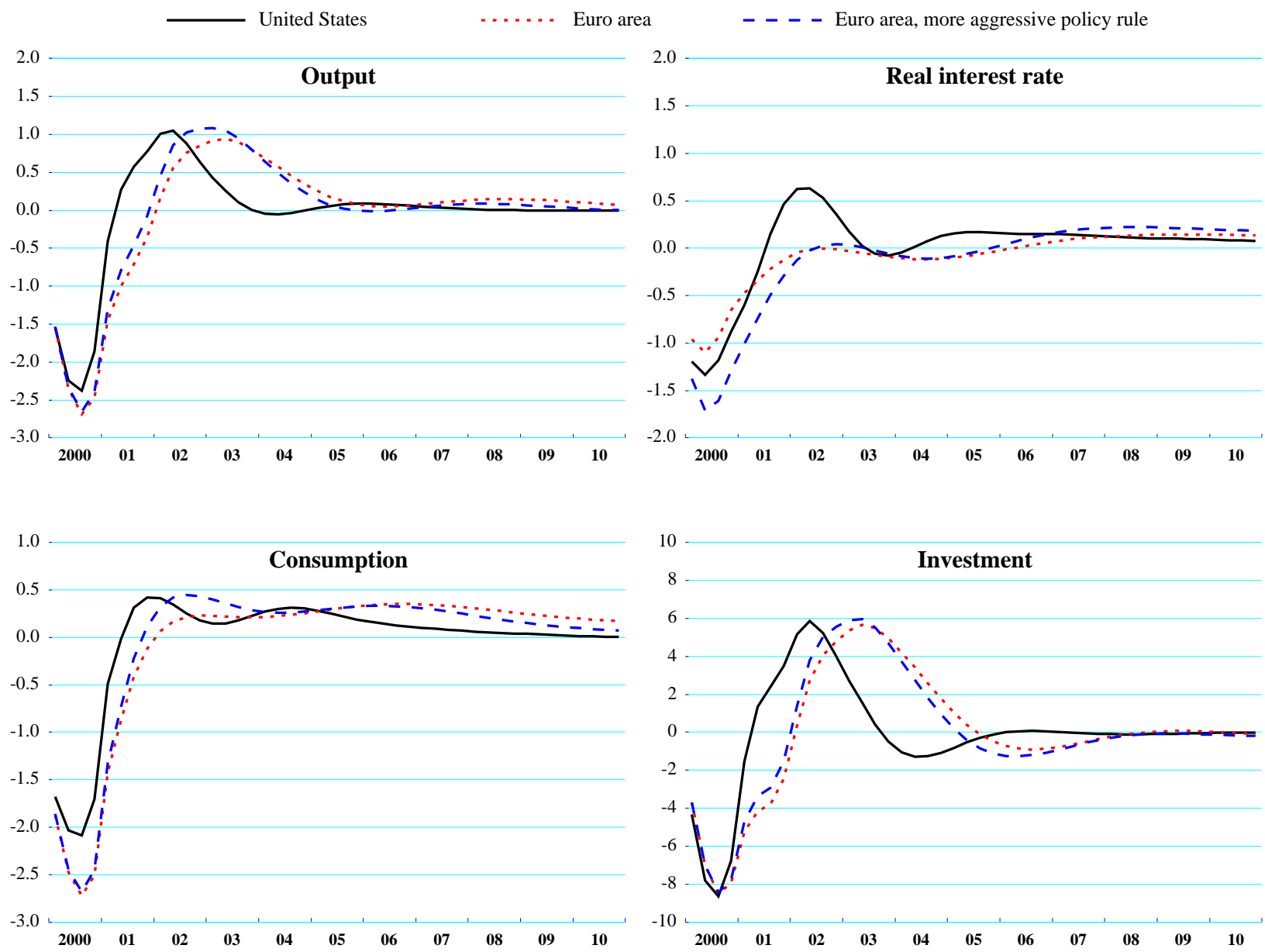

1.0

Price inflation

0.5

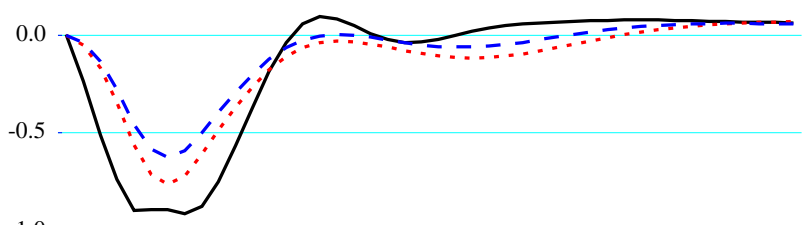

$\begin{array}{lllllllllll}1.5 & & & & & & & & & & \\ 2000 & 01 & 02 & 03 & 04 & 05 & 06 & 07 & 08 & 09 & 10\end{array}$ Source : OECD.
2.0

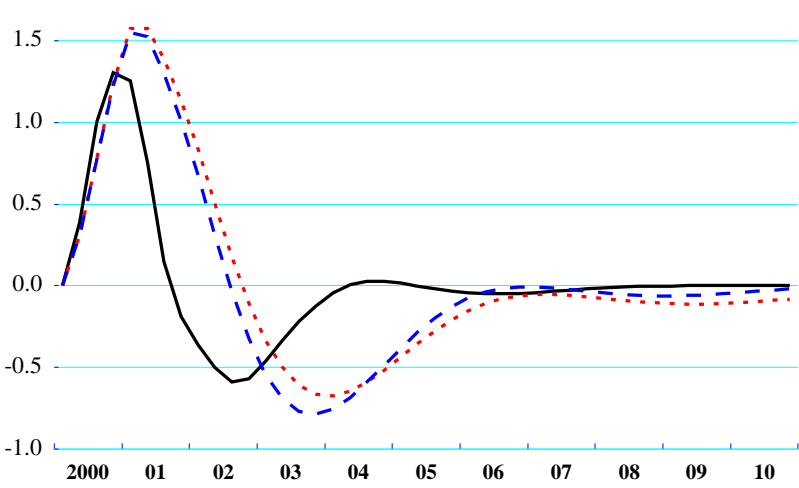


Figure 9. Sensitivity tests : very aggressive policy rule Per cent deviation from baseline
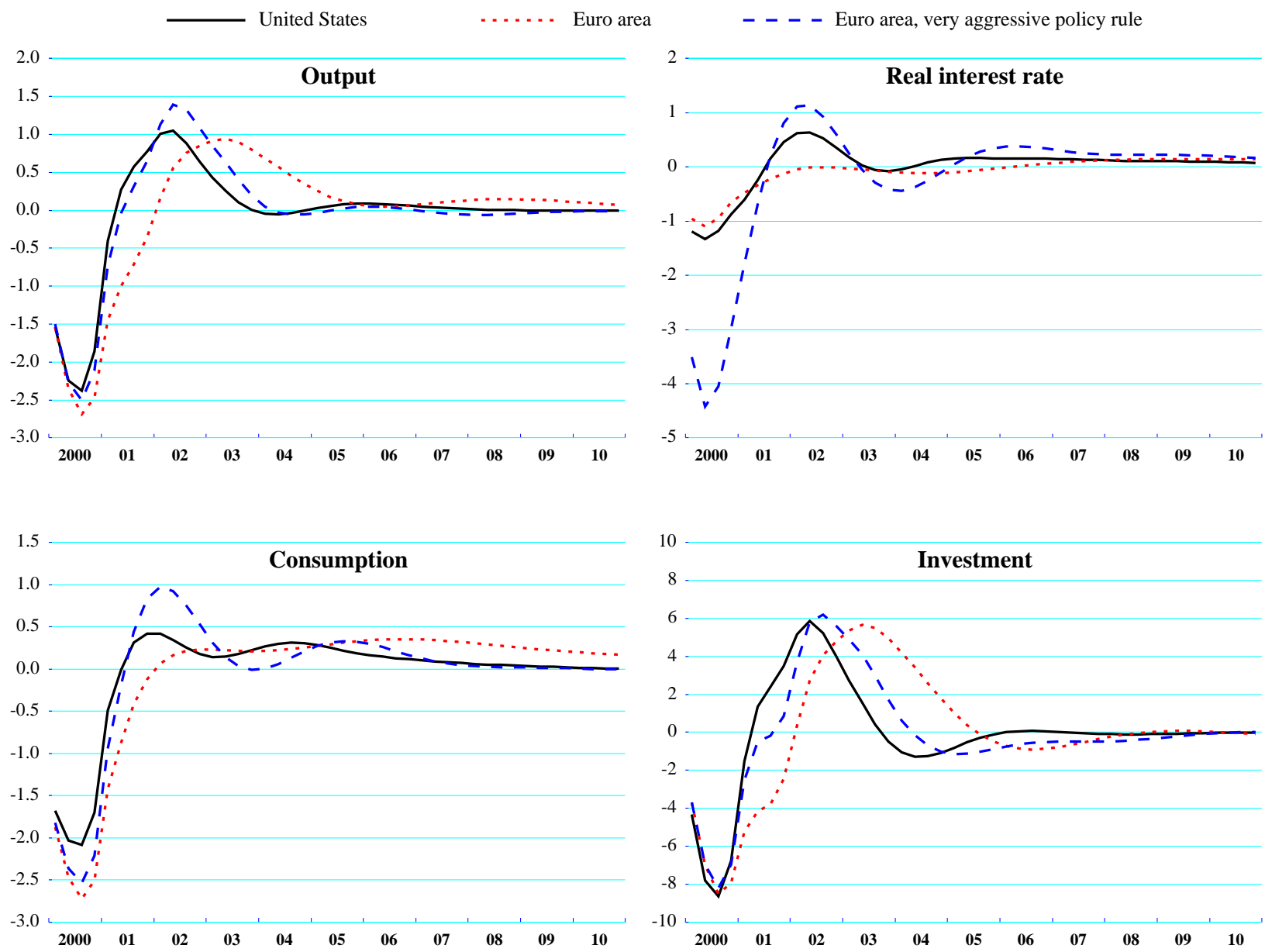

1.0

Price inflation

0.5

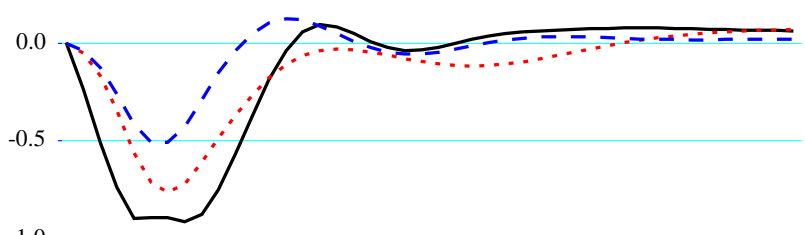

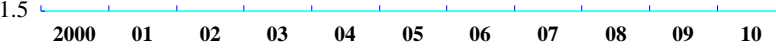
Source : OECD
2.0

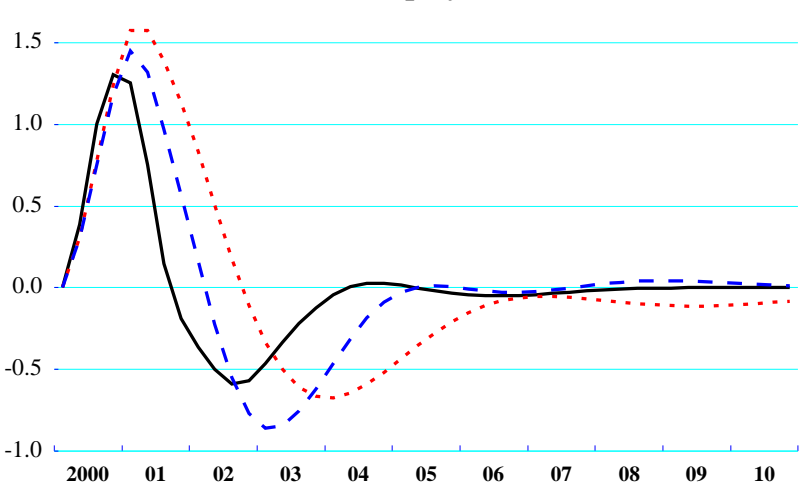




\section{ECO/WKP(2004)5}

Figure 10. Loss of the euro-area economy relative to the US economy under different shocks

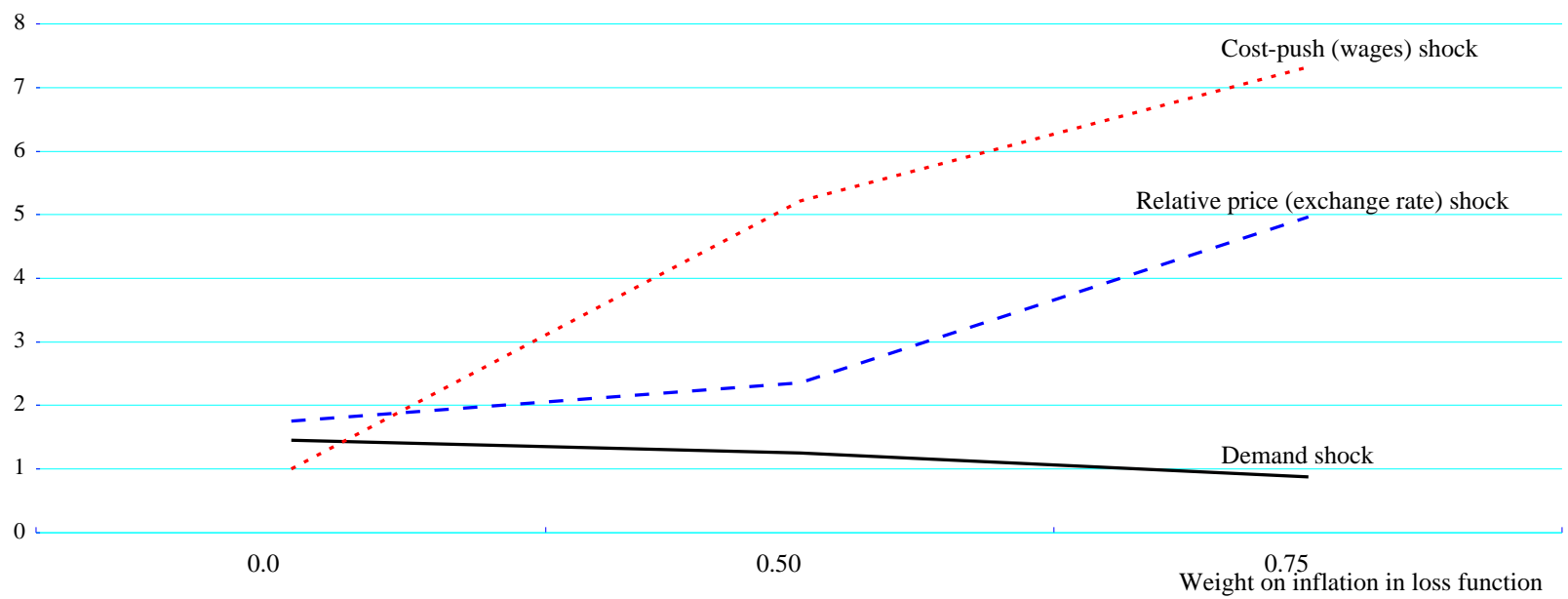

Note : The measures of loss are calculated using a standard quadratic loss function that penalises the squared deviation of output and inflation from their equilibrium or target rates. The deviations are subject to a quarterly discount rate of 0.99 (or around 4 per cent per annum), as commonly applied in the literature.

The loss from the US economy is used to normalise outcomes. Hence, a value greater than 1 implies that the euro area economy performs worse under a given shock relative to the US economy and vice versa.

Source : OECD. 


\section{WORKING PAPERS}

The full series of Economics Department Working Papers can be consulted at www.oecd.org/eco/Working_Papers/

381. Product Market Competition and Economic Performance in Hungary

(March 2004) Carl Gjersem, Philip Hemmings and Andreas Reindl

380. Enhancing the Effectiveness of Public Spending: Experience in OECD Countries

(February 2004) Isabelle Joumard, Per Mathis Kongsrud, Young-Sook Nam and Robert Price

379. Is there a Change in the Trade-Off between Output and Inflation at Low or Stable Inflation Rates?

Some Evidence in the Case of Japan

(February 2004) Annabelle Mourougane and Hideyuki Ibaragi

378. Policies bearing on product market competition and growth in Europe

(January 2004) Carl Gjersem

377. Reforming the Public Expenditure System in Korea

(December 2003) Young-Sook Nam and Randall Jones

376. Female Labour Force Participation: Past Trends and Main Determinants in OECD Countries

(December 2003) Florence Jaumotte

375. Fiscal Relations Across Government Levels

(December 2003) Isabelle Joumard and Per Mathis Kongsrud

374. Health-Care Systems: Lessons from the Reform Experience

(December 2003) Elizabeth Docteur and Howard Oxley

373. Non-Tariff Measures Affecting EU Exports: Evidence from a Complaints-Inventory

(December 2003) Peter Walkenhorst and Barbara Fliess

372. The OECD Medium-Term Reference Scenario: Economic Outlook No. 74

(November 2003) Peter Downes, Aaron Drew and Patrice Ollivaud

371. Coping with Ageing: A Dynamic Approach to Quantify the Impact of Alternative Policy Options on Future Labour Supply in OECD Countries

(November 2003) Jean-Marc Burniaux, Romain Duval and Florence Jaumotte

370. The Retirement Effects of Old-Age Pension and Early Retirement Schemes in OECD Countries

(November 2003) Romain Duval

369. Policies for an Ageing Society: Recent Measures and Areas for Further Reform

(November 2003) Bernard Casey, Howard Oxley, Edward Whitehouse, Pablo Antolin, Romain Duval, Willi Leibfritz

368. Financial Market Integration in the Euro Area (October 2003) Carl Gjersem

367. Recent and Prospective Trends in Real Long-Term Interest Rates: Fiscal Policy and Other Drivers (September 2003) Anne-Marie Brook

366. Consolidating Germany's finances: Issues in public sector spending reform (September 2003) Eckhard Wurzel 


\section{ECO/WKP(2004)5}

365. Corporate Taxation of Foreign Direct Investment Income 1991-2001

(August 20030) Kwang-Yeol Yoo

364. Indicator Models of Real GDP Growth in Selected OECD Countries (July 2003) Franck Sédillot and Nigel Pain

363. Post-Crisis Change in Banking and Corporate Landscapes - the Case of Thailand (July 2003) Margit Molnar

362. Post-Crisis Changes in Banking and Corporate Landscapes in Dynamic Asia (June 2003) Margit Molnar

361. After The Telecommunications Bubble (June 2003) by Patrick Lenain and Sam Paltridge

360. Controlling Public Spending in Iceland (June 2003) Hannes Suppanz

359. Policies and International Integration: Influences on Trade and Foreign Direct Investment (June 2003) Giuseppe Nicoletti, Steve Golub, Dana Hajkova, Daniel Mirza, Kwang-Yeol Yoo

358. Enhancing the Effectiveness of Public Spending in Finland (June 2003) Philip Hemmings, David Turner and Seija Parviainen

357. Measures of Restrictions on Inward Foreign Direct Investment for OECD Countries (May 2003) Stephen S. Golub

356. Tax Incentives and House Price Volatility in the Euro Area: Theory and Evidence (May 2003) Paul van den Noord

355. Structural Policies and Growth: A Non-technical Overview (May 2003) Alain de Serres

354. Tax Reform in Belgium (May 2003) David Carey

353. Macroeconomic Policy and Economic Performance (April 2003) Pedro de Lima, Alain de Serres and Mike Kennedy

352. Regulation and Investment (March 2003) Alberto Alesina, Silvia Ardagna, Giuseppe Nicoletti and Fabio Schiantarelli

351. Discretionary Fiscal Policy and Elections: The Experience of the Early Years of EMU (March 2003) Marco Buti and Paul van den Noord

350. The US Health System: An Assessment and Prospective Directions for Reform (February 2003) Elizabeth Docteur, Hannes Suppanz and Jaejoon Woo

349. The Effectiveness of Public Expenditure in Portugal (February 2003) Chiara Bronchi

348. Comparative Analysis of Firm Demographics and Survival: Micro-Level Evidence for the OECD Countries (February 2003) Eric Bartelsman, Stefano Scarpetta and Fabiano Schivardi

347. Regulation, Productivity and Growth: OECD Evidence

(January 2003) Giuseppe Nicoletti and Stefano Scarpetta 